\title{
柴达木盆地北缘侏罗纪沉积物源分析：地层序列 及LA-ICP-MS年代学信息
}

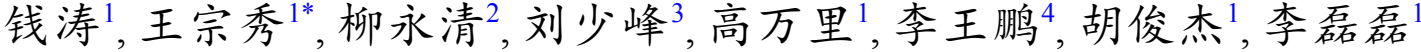 \\ 1. 中国地质科学院地质力学研究所, 中国地质科学院页岩油气评价重点实验室, 北京 100081 ; \\ 2. 中国地质科学院地质研究所, 北京 100037 ; \\ 3. 中国地质大学地质过程与矿产资源国家重点实验室, 北京 100083; \\ 4. 中国石化石油勘探开发研究院, 北京 100083 \\ *通讯作者, E-mail: wangzongxiu@sohu.com
}

收稿日期: 2017-04-12; 接受日期: 2017-10-18; 网络版发表日期: 2017-12-01

中国地质调查局项目(编号: 12120115003401)和国家自然科学基金项目(批准号: 41702238, 41602125)资助

\begin{abstract}
摘要柴达木盆地北缘(柴北缘)出露侏罗纪地层, 其中以大煤沟地区发育最为完整. 整个侏罗系发育具 有辫状河河道、滨浅湖及辫状河三角洲沉积体系特征的地层序列, 厚度达到 $1100 \mathrm{~m}$. 利用地层序列、砂岩 碎屑组分及LA-ICP-MS微区定年方法, 对柴北缘侏罗系沉积物源体系进行了研究. 砂岩Dickinson图解显示 其主要来源于再旋回造山带、碰撞缝合带和褶皱-逆冲带物源区.砂岩碎屑锆石U-Pb年代学同位素分析结果 表明, 早侏罗世具有1764 2496Ma(峰值年龄1787、2077和2440Ma); 中晚侏罗世具有相同的年龄谱特征, 分 别是 197 291Ma(峰值年龄 238Ma), 214 278Ma(峰值年龄238Ma); 358 484Ma(峰值年龄 404Ma), 370 456Ma(峰 值年龄 418Ma); 645 920Ma(峰值年龄 875Ma), 578 1160Ma(峰值年龄 940Ma); 1390 1991Ma(峰值年龄 1875Ma), 1550 1829Ma(峰值年龄1708Ma); 2048 2484Ma(峰值年龄2272Ma), 2161 2738Ma(峰值年龄2335Ma). 研究表明, 柴北缘侏罗纪沉积物源区由全吉地块(早侏罗世)扩大至柴北缘构造带、全吉地块、祁连山(中晚侏罗世). 沉积 物源区的显著变化是早中侏罗世之交发生的强烈构造运动在柴达木盆地内部的沉积物质表现.
\end{abstract}

关键词柴达木盆地, 侏罗纪, 沉积物源, LA-ICP-MS 年代学

\section{1 引言}

沉积物是联系盆地与造山带的 “纽带”, 是构造演 化和盆地形成的直接证据和重要标志, 它包含了源区 山脉在不同演化阶段的原始构造面貌、隆升剥露历 史和盆山几何配置关系的诸多信息. 对盆地沉积地层
进行源区研究用到一系列分析方法, 如测量并恢复古 水流方向(砾岩最大扁平面定向排列)(Qian等, 2015), 常规碎屑成分统计(刘云生等, 2006; Liu等, 2005)、 重矿物组合(李林林等, 2015; 李俊武等, 2015a, 2015b) 等, 然而由于盆地沉积物源的多样性、复杂性、不 同源区贡献的差异性以及受碎屑物质在搬运过程中

中文引用格式: 钱涛, 王宗秀, 柳永清, 刘少峰, 高万里, 李王鹏, 胡俊杰, 李否磊. 2018. 柴达木盆地北缘侏罗纪沉积物源分析: 地层序列及LA-ICP-MS年代 学信息. 中国科学: 地球科学, 48: 224-242, doi: 10.1360/N072017-00119

英文引用格式： Qian T, Wang Z X, Liu Y Q, Liu S F, Gao W L, Li W P, Hu J J, Li L L. 2018. Provenance analysis of the Jurassic northern Qaidam Basin: Stratigraphic succession and LA-ICP-MS geochronology (in Chinese). Scientia Sinica Terrae, 48: 224-242, doi: 10.1360/N072017-00119 
的分异作用影响, 仅单纯利用以上方法研究岩屑分散 型式、分析源区性质和特征等(Tucker和 Slingerland, 1996; DeCelles等, 1998) 是不够的. 国内外学者还将岩 石学、同位素地球化学及同位素年代学方法应用于盆 地沉积物研究中, U-Pb锆石年龄谱研究成功地示踪了 沉积物物源区物质组成、构造面貌, 造山带核部高压 变质岩初始剥露时间、剥露过程(Enkelmann等, 2007; Liu等, 2010). 由此可见, 盆地沉积物研究在沉积盆地 分析方面已经成为一种系统的研究方法.

柴达木盆地含有丰富的油气和矿产资源, 吸引了 大批学者从构造、沉积、地球化学和地球物理等方 面开展了大量研究工作并取得了重要的成果. 长期以 来, 特别是中生代以侏罗纪为代表的盆地研究积累了 丰富的资料, 开展了侏罗纪盆地性质(曾联波等, 2002), 以及侏罗纪沉积相、地层发育迁移、展布规律、构 造-沉积演化(汤良杰等, 2000; 杨永泰等, 2001; 李伟 等, 2002; 曹国强等, 2005; 金振奎等, 2006; 蒋荣宝等, 2008; 邵龙义等, 2014)等方面的探讨. 现今更多的学者 关注柴达木盆地新生代的沉积物源(付玲等, 2013; 李 林林等, 2015; 李俊武等, 2015a, 2015b; Jian等, 2013). 然而, 除少数学者从地球化学角度进行了初步研究外 (Cao等, 2012; Jian等, 2013), 到目前为止对侏罗纪盆地 沉积物物源研究仍然是一片空白, 从而制约了侏罗纪 原型盆地复原、盆山耦合关系建立、油气资源勘探 等问题的深入研究. 因此, 柴北缘侏罗纪沉积物源体
系是亟需解决的问题.

\section{2 区域地质背景}

柴达木盆地位于青藏高原东北缘(图1), 是一个典 型的中新生代陆内盆地, 以沉积巨厚的新生代地层为 显著特征. 柴达木盆地北缘与柴北缘构造带和祁连山 构造带、西缘与阿尔金山构造带、南缘与东昆仑山 构造带相连. 柴达木盆地的形成和演化, 始终与特提 斯-喜马拉雅构造域的强烈活动有关(邵龙义等, 2014). 柴北缘构造带、祁连山构造带、阿尔金山构造带和 东昆仑山构造带在是否为柴北缘提供侏罗纪沉积碎 屑物质方面具有重要的意义.

\section{1 柴北缘构造带}

柴北缘构造带是加里东期重要的造山带, 记录了 柴达木地块向北俯冲于祁连地块之下并发生陆陆碰撞 的过程(Song等, 2012, 2014b). 柴北缘构造带岩性主要 由高压-超高压变质岩、岛弧火山岩、古生代花岗岩 和志留纪之后的沉积盖层组成(Mattinson等, 2006; Shi 等, 2006; Song等, 2006, 2007; Xiong等, 2012). 高压-超 高压变质岩带中榴辉岩、石榴石橄榄岩和石榴石辉石 岩集合体呈透镜体状或块状出露于柴北缘构造带的赛 什腾山、嫩唠山、绿梁山和锡铁山等地区 (Mattinson 等, 2006; Song等, 2006, 2007; 图1). 晚二叠世到三叠 纪, 柴北缘构造带经历了印支期构造变形作用, 与其伴

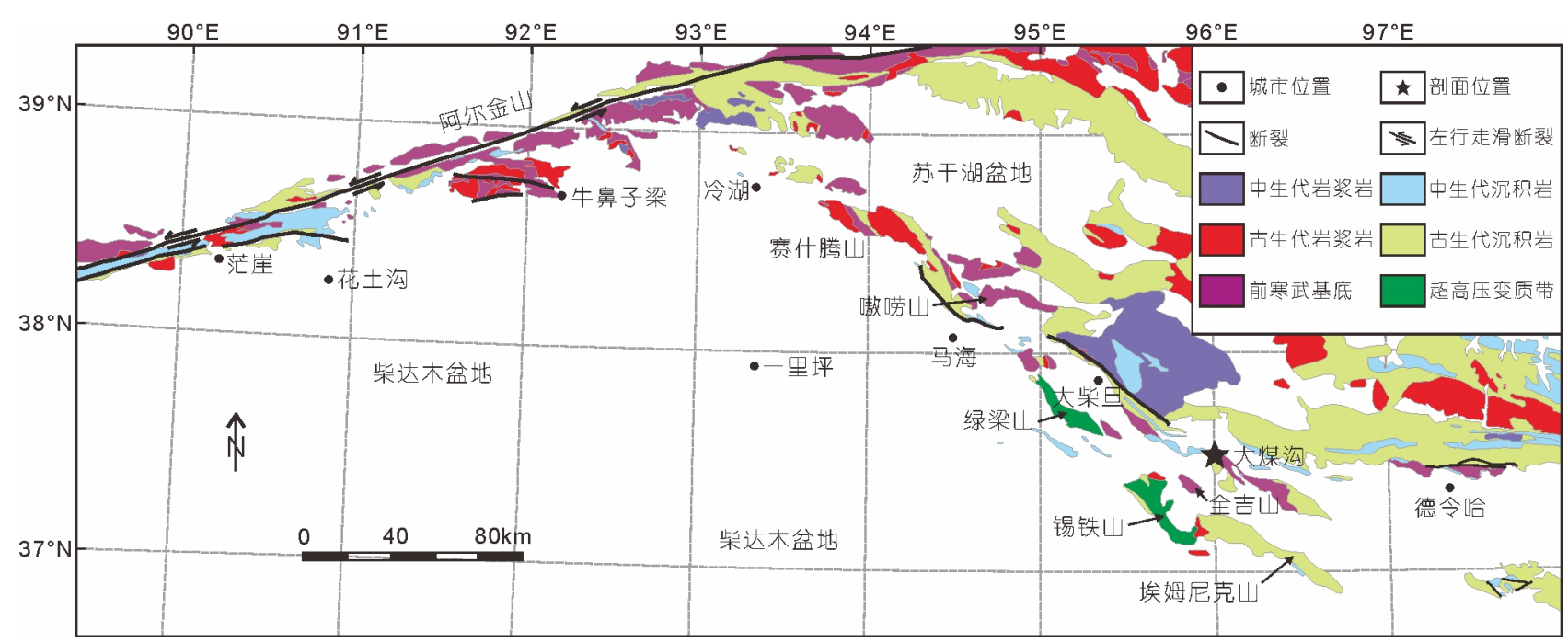

图 1 柴达木盆地北缘区域地质简图(Song等, 2006, 2014a, 2014b)

图中五角星所示位置为大煤沟侏罗系实测剖面及碎屑锆石样品采样点 
随产出的花岗岩、花岗岩类岩石及其他岩浆岩(吴才 来等, 2008; 彭渊等, 2016)在赛什腾山及柴北缘东段地 区有较好的出露(图1).

\section{2 祁连山构造带}

祁连山构造带由多条北西-南东走向的山脉组成, 其西端在当金山口与阿尔金山构造带相接. 祁连山造 山带是一条典型的缝合带, 记录了新元古代到古生代 期间发生的大陆裂解、洋盆形成、陆陆碰撞的过程 (Song等, 2013), 从北向南由北祁连构造带、中祁连山 和南祁连构造带组成. 其中, 南祁连构造带是柴达木 盆地北缘的分界线.

\section{3 阿尔金山构造带}

阿尔金山构造带由一系列北东向断裂组成, 介于 塔里木盆地和柴达木盆地之间. 前人大量的研究表 明, 阿尔金断裂带经历了多期构造变形作用, 在形成 和演化历史方面提出了多种假设. Sobel等(2001)指出, 阿尔金断裂系统在侏罗纪时期经历了构造抬升和冷 却作用阶段, 这一作用与晚三叠世-早侏罗世青藏高 原的地体拼合过程有关; Wang等(2005)指出阿尔金断 裂带经历了三期构造事件: 大约在250 230Ma初步发 生了左旋走滑剪切作用, 接下来的两期(165 160Ma和 100 89Ma)构造作用只发生了左旋走滑变形并未发生 挤压作用. 然而, 大量研究成果指示阿尔金构造带在 中生代晚期、新生代早期甚至在新生代中期之后开 始形成, 其形成原因归结为印度板块和欧亚板块的碰 撞(Tapponnier等, 1986; Wang, 1997; Wang等, 2005).

\section{4 东昆仑山构造带}

东昆仑山构造带近东西走向位于青藏高原北部. 东昆仑山构造带基底主要由元古代和古生代变质岩 组成, 上部被古生代和中生代地层所覆盖. 古生代至 三叠纪, 东昆仑山构造带大面积发生岩浆作用, 后期被 新生代陆相碎屑沉积物质覆盖(Yin等, 2007; Cheng等, 2016). 前人大量的研究成果指示了东昆仑山开始活动 时间为30 20Ma(Yuan等, 2003; Zhang等, 2004; Cheng 等, 2014)或始新世-渐新世到中新世, 甚至晚渐新世-中 中新世时期(Yuan等, 2003; Yin等, 2007; Mao等, 2014).

\section{3 柴北缘侏罗系沉积序列特征}

侏罗系主要在柴北缘和阿尔金山前地带较发育 (图1). 下侏罗统发育湖西山组、小煤沟组地层, 中侏 罗统发育大煤沟组地层, 上侏罗统发育采石岭组、红 水沟组地层. 侏罗系底部呈角度不整合或平行不整合 关系上覆于古元古界达肯大阪群、奥陶系或石炭系 不同地层之上, 顶部与白严系或新生界地层呈角度不 整合或平行不整合接触.

侏罗系发育残缺不全、零星分布, 其中大煤沟地 区为发育较完整的剖面(图1). 下文将以大煤沟剖面为 例说明侏罗系地层序列特征.

\section{1 下侏罗统地层序列特征}

大煤沟剖面侏罗系(图2)出露较好, 较完整地记录 了侏罗纪沉积充填作用, 厚度达 $1100 \mathrm{~m}$. 下侏罗统小煤 沟组厚度约为 $100 \mathrm{~m}$, 角度不整合于古元古界达肯大坂 群之上, 总体向上变细, 内部由约 3 个向上变细的小序 列组成. 序列底部发育厚约 $2 \mathrm{~m}$ 的中砾岩, 红棕色, 块 状构造 (图3a). 砾岩以中砾石为主夹粗砾石, 分选较 差, 棱角-次棱角状; 砾石岩性主要为石英岩状砂岩; 颗 粒支撑, 少量砂质填隙物. 该部分被解释为僢状河河 床底部滞留沉积. 砾岩向上为含砾砂岩、中砂岩、粉 砂岩及炭质泥岩组合; 砂体中发育水平层理、块状层 理、平行层理(图3b)、板状交错层理(图3c)及槽状层 理. 序列中常见菱铁矿结核. 序列顶部从薄层含砾砂 岩到厚层中-粗砂岩, 从岩性组合、旋回特征、沉积构 造及生物化石等特征表明序列发育的沉积环境从辫 状河河道到滨浅湖, 具有典型的“下粗上细”特征.

\section{2 中侏罗统地层序列特征}

大煤沟组构成了中侏罗统, 厚度较之小煤沟组大 幅增加到 $860 \mathrm{~m}$. 整个大煤沟组主要由数个向上变粗 的反旋回序列组成, 局部发育向上变细的正旋回序列. 大煤沟组地层序列岩石色调主要从灰黑-黑色到上部 的紫红色或紫红-灰绿色, 反映了从潮湿还原到干旱氧 化环境的转变. 下部为厚层炭质泥岩-泥岩(图3d)、互 层粉砂岩夹薄层细砂岩. 炭质泥岩-泥岩中频繁发育 条带状或透镜体状砂岩, 并见菱铁矿结核 (图3e)及大 量植物碎片化石(图3f). 序列上部发育砾岩、含砾砂 


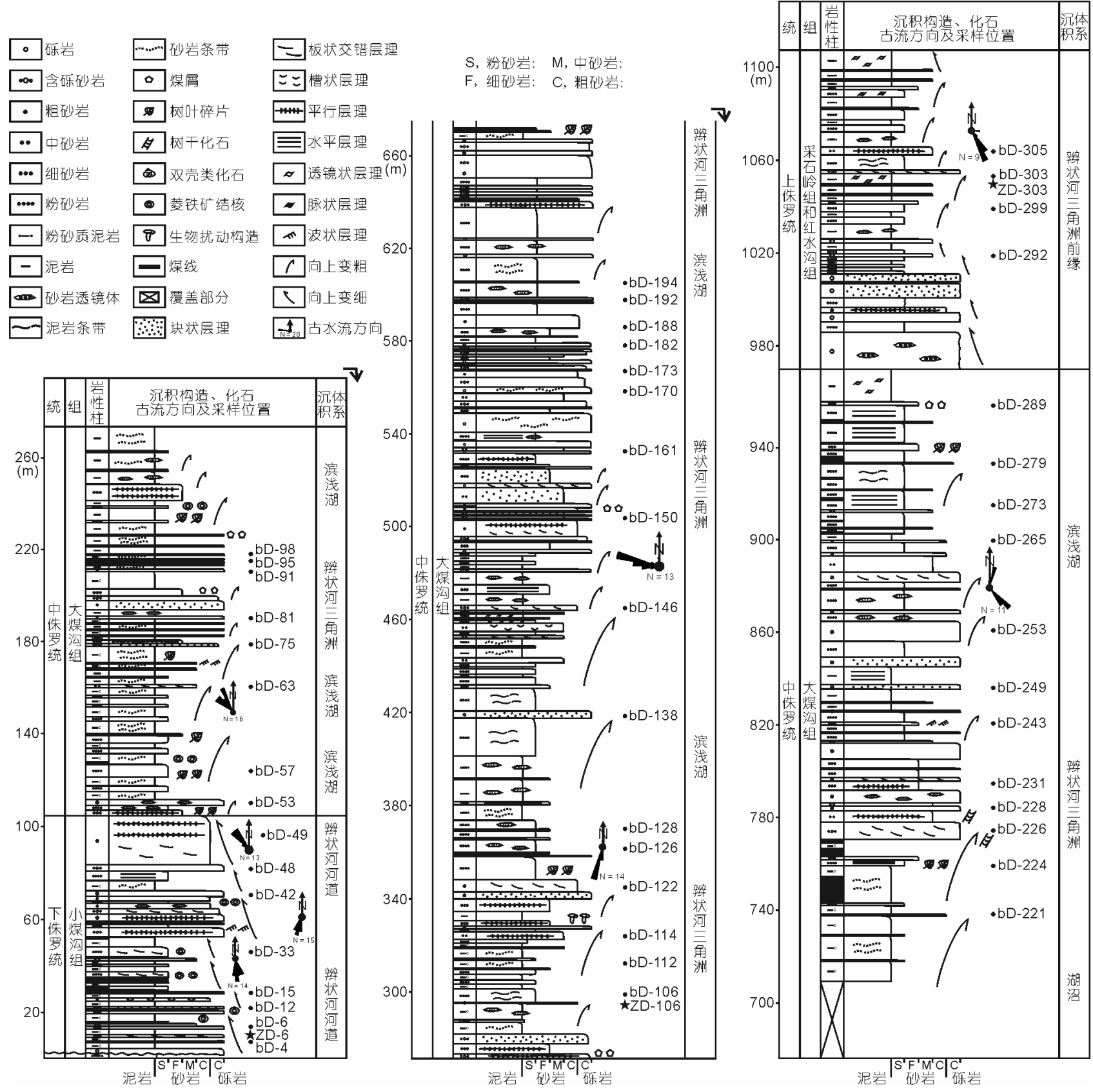

图 2 大煤沟地区侏罗系地层柱状图

剖面位置见图1. 图中黑色圆点标记碎屑薄片采样点, 五角星标记碎屑锆石采样点

岩、细砂岩及薄层泥岩, 砾岩及砂岩中发育平行层 理、板状交错层理、槽状层理及块状层理并夹大量 煤屑, 薄层泥岩具有与下部细粒碎屑物质相似的沉积 特征. 大煤沟组上部序列中发育紫红色粉砂岩-粉砂 质泥岩夹灰绿色条带状或透镜体状细砂岩, 有时两者
混成一片, 分不清层理面. 紫红色细粒碎屑物质中常 见透镜状层理、脉状层理及波状复合层理, 灰绿色细 砂岩中发育生物扰动构造(图3g). 整个大煤沟组地层 序列发育于滨浅湖、辫状河三角洲沉积环境, 并且以 频繁发育的煤层为显著特征. 

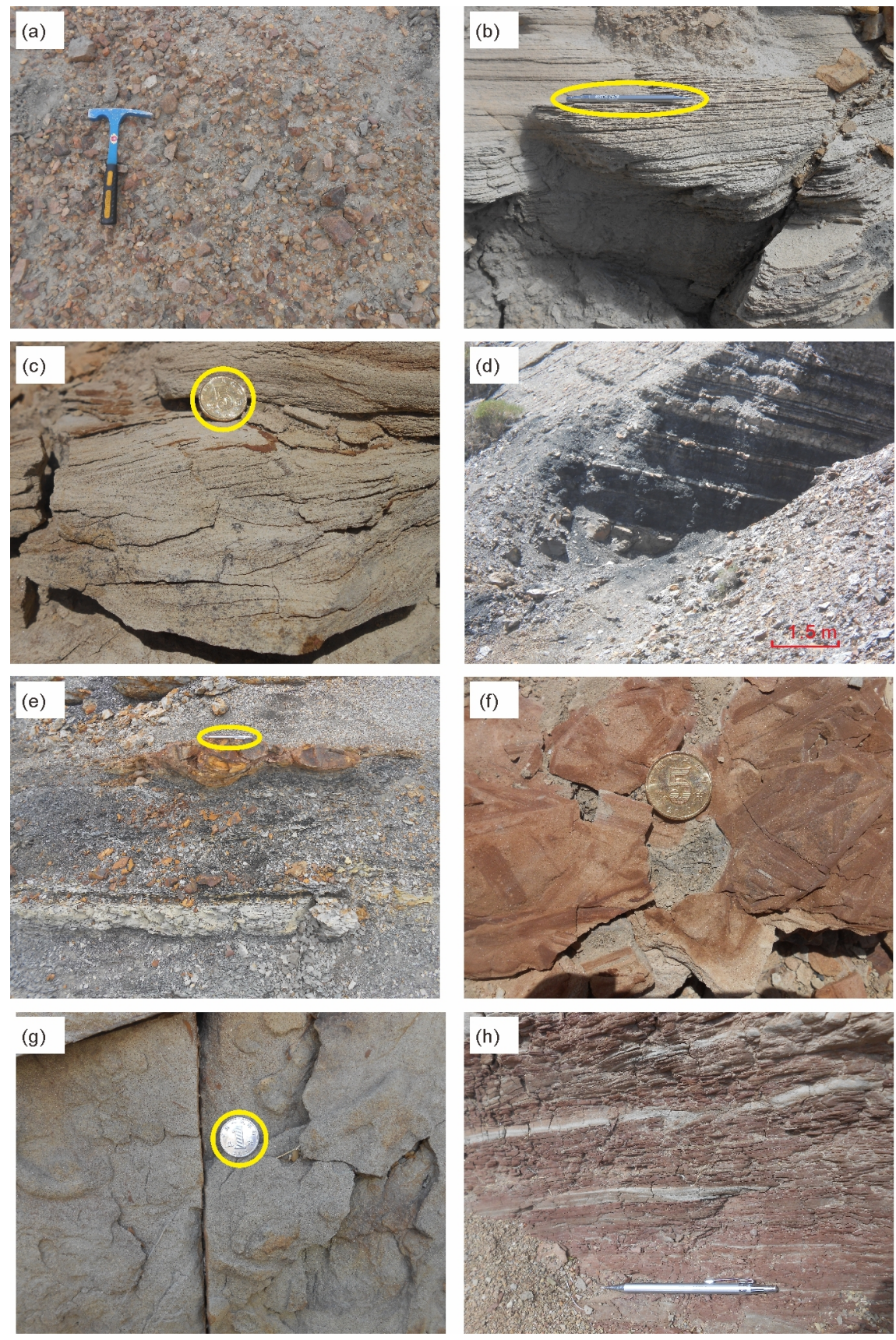

图 3 大煤沟剖面侏罗系地层序列野外照片

(a) 小煤沟组辫状河河道滞留砾岩; (b) 小煤沟组粗砂岩中平行层理; (c) 小煤沟组砂岩中板状交错层理; (d) 大煤沟组炭质泥岩-泥岩夹条带 状细砂岩; (e) 大煤沟组炭质泥岩中菱铁矿结核; (f) 大煤沟组细砂岩中植物碎片化石; (g) 大煤沟组㲔状河三角洲前缘砂岩中生物扰动构造; (h) 红水沟组紫红色粉砂质泥岩-泥岩与灰绿色粉砂岩互层夹薄层中砂岩

\section{3 上侏罗统地层序列特征}

大煤沟剖面上侏罗统由采石岭组和红水沟组组成, 厚度近 $150 \mathrm{~m}$. 总体以紫红色粉砂岩、粉砂质泥岩、 泥岩与灰绿色中-粗粒砂岩为主(图3h), 反映干旱氧化 气候. 地层序列主体由多个向上变粗的反旋回组成. 每个小层序具有几乎相似的特征. 序列下部为紫红色 粉砂岩、粉砂质泥岩、泥岩或三者互层, 发育脉状层 
理、透镜状层理或波状层理, 反映双向水流动力条件. 互层中夹薄层细砂岩-粉砂岩, 发育平行层理、水平 层理, 为三角洲前缘席状砂, 形成于三角洲进入水体 的环境. 席状砂向上发育变粗的泥岩-粉砂岩-细砂岩 韵律层, 砂体中可见平行层理和小型交错层理, 为河 口坝沉积. 粉砂岩和泥岩中常夹砂岩透镜体, 横向延 伸数米即变薄尖灭或渐变为砂岩条带, 与泥岩的界线 有时不易区分, 为三角洲前缘分流河道间沉积. 河道 间沉积体上部往往发育厚度不等的细砂岩、中砂岩, 分布稳定, 发育板状-小型槽状-楔状交错层理和平行 层理, 局部可见冲刷-充填构造, 为水下分流河道沉积. 在小序列上部一般发育层厚不等的灰绿色中-粗砂岩, 砂体内部发育平行层理、槽状层理、板状交错层理 及楔状交错层理. 综合分析, 上侏罗统地层序列为一 套辫状河三角洲前缘沉积物.

\section{4 样品和测试方法}

实测大煤沟剖面过程中, 在重要层位采集了砂岩 碎屑薄片和锆石测年样品. 砂岩组分实验通过显微镜 观察, 采用Gazzi-Dickinson 显微镜统计方法 (Dickinson 等, 1979), 在单个薄片上完成500 600个颗粒的统计, 再运用砂岩三角图解分析源区特征. 碎屑锆石样品的 粉碎、锆石挑选与制靶、透反光及阴极发光照片都 在河北省廊坊市峰泽源岩矿检测技术有限公司完成. LA-ICP-MS锆石U-Pb测试工作在吉林大学东北亚矿产 资源评价国土资源部重点实验室完成, 每个样品随机 选择 120 颗锆石进行测试. 激光剥蚀束斑直径 $32 \mu \mathrm{m}$. 首 先采集30s的背景, 随后进行30s的样品剥蚀. 使用标准 锆石91500作为外标进行同位素比值校正. 元素含量以 国际标样NIST610为外标, $\mathrm{Si}$ 为内标元素进行计算. 使 用Glitter软件进行同位素比值及元素含量的计算. 谐和 年龄及图像使用Isoplot(3.0)给出(Ludwig, 2003). 对于 大于 $10 \mathrm{Ga}$ 的年龄采用 $100 \times\left({ }^{207} \mathrm{~Pb} /{ }^{206} \mathrm{~Pb}\right) /\left({ }^{206} \mathrm{~Pb} /{ }^{238} \mathrm{U}\right)$, 年 龄小于 $10 \mathrm{Ga}$ 的采用 $\left.100 \times\left({ }^{207} \mathrm{~Pb} /{ }^{235} \mathrm{~Pb}\right) /{ }^{206} \mathrm{~Pb} /{ }^{238} \mathrm{U}\right)$ 分别计 算锆石测年结果的谐和度. 将谐和度在90 110\%之内 的数据视为有效年龄, 分析数据及锆石U-Pb谐和图给 出误差为 $1 \sigma$.

\section{5 砂岩碎屑组分}

总体而言, 大煤沟组侏罗系砂岩碎屑组分通过
Qt-F-L、Qm-F-Lt和Qp-Lv-Ls三种方式投图指示了沉 积物物源区落在再旋回造山、碰撞缝合带、褶皱-逆 冲带及岩浆弧造山带区域(图4). 因此, 柴北缘侏罗系 沉积物可能来自柴北缘构造带、祁连山.

\section{6 锆石 LA-ICP-MS U-Pb年龄}

碎屑锆石测年样品采自大煤沟剖面下侏罗统小 煤沟组含砾粗砂岩(ZD-6)、中侏罗统大煤沟组粗砂 岩(ZD-106)及上侏罗统采石岭组和红水沟组细砂岩 (ZD-303)(采样位置见图2).

\section{1 锆石形貌特征}

三个样品中锆石形貌多样且显示了复杂的内部 结构. 样品ZD-6、ZD-106和ZD-303锆石粒径分别是 87 283、57 137、109 304 $\mu \mathrm{m}$. 粒径不等, 相差较大, 其中样品ZD-106中锆石粒径总体较小. 大多数锆石呈 柱状, 少数为等粒状或不规则状. 部分锆石晶形完好, 基本没有磨圆; 阴极发光图像显示具有典型的岩浆韵 律环带, 且没有变质增生边(图5), 分析可能属于构造 岩浆活动的产物; 部分锆石阴极发光显示呈灰白色或 白色, 可能是因为后期强烈的结晶作用几乎全部置换 了锆石原始生长环带(图5); 这些锆石往往具有大于 $1000 \mathrm{Ma}$ 的年龄信息. 锆石的形貌特征显示了其不同 类型的成因, 可能反映了较为复杂的物源信息.

\section{2 锆石微量元素特征}

样品 ZD-6和 ZD-106 中锆石的稀土元素总量 较高且变化范围大, ZD-303 的稀土元素范围为 32.96 3370.38ppm(表 1). 三个样品中绝大部分锆 石的稀土元素球粒陨石标准化型式表现为重稀土 元素(HREE) 呈富集趋势 $\left((\mathrm{Lu} / \mathrm{Gd})_{\mathrm{N}}\right)$ 、轻稀土元素 (LREE) 亏损(表1, 图6). 重稀土元素(HREE)部分较陡 $\left((\mathrm{Yb} / \mathrm{Sm})_{\mathrm{N}}\right)($ 表 1 , 图6). 具有较明显的Ce正异常 $(\delta \mathrm{Ce})$ 和 $\mathrm{Eu}$ 负异常 $(\delta \mathrm{Eu})$ (表1, 图6), 显示岩浆成因锆石的特征 (Vavra等, 1996; Miller等, 1998), 少部分锆石不具有岩 浆锆石稀土元素配分特征(图6).

总体而言, 3 个砂岩样品中大多数锆石的 $\mathrm{Th} / \mathrm{U}$ 比值 大于 0.4 . ZD-6样品中 $\mathrm{Th} / \mathrm{U}$ 大于 0.4 的颗粒有 57 个, 约占 $97 \%$ (图7). ZD-106样品中 Th/U大于 0.4 的颗粒有 69 个, 

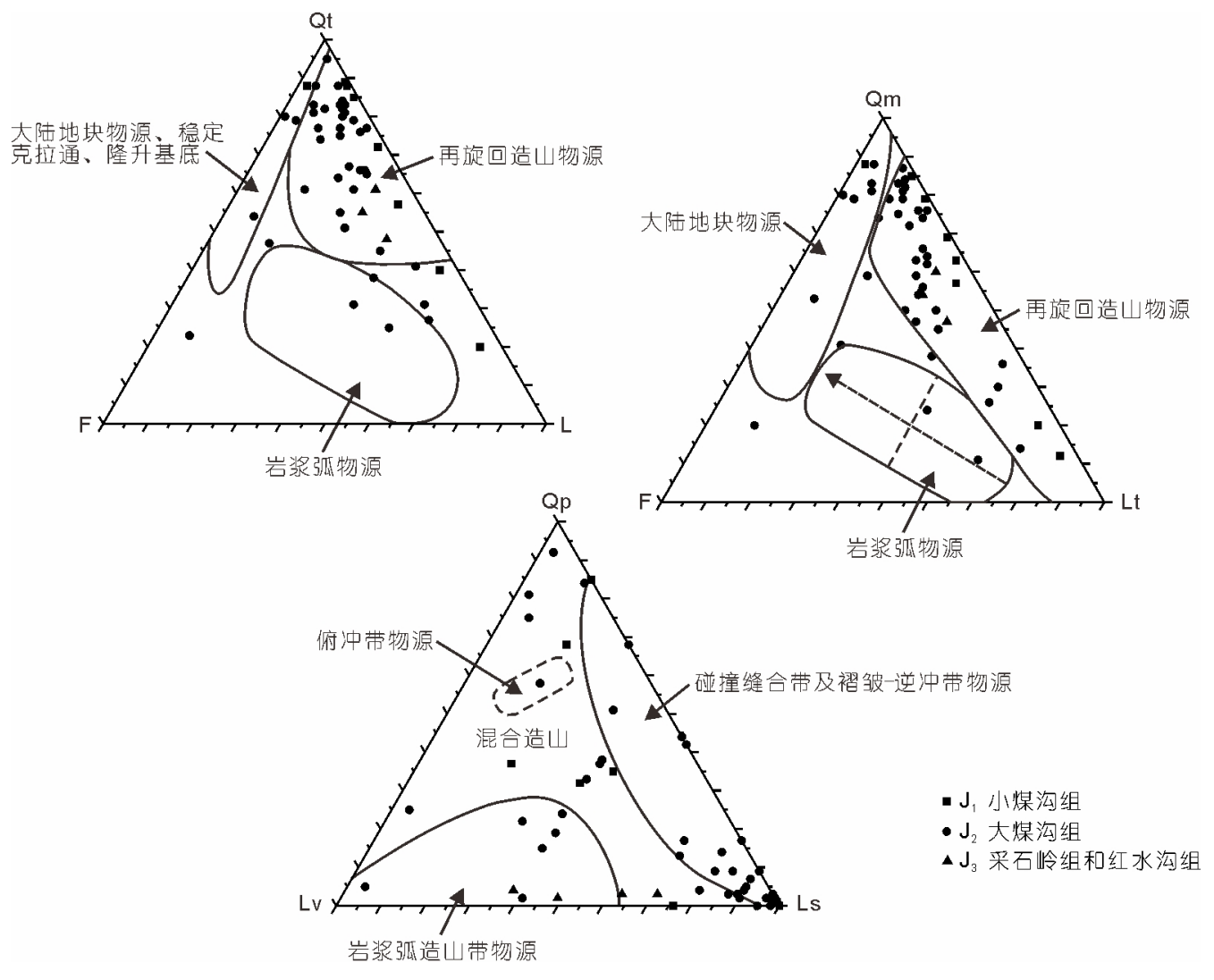

图 4 大煤沟剖面砂岩Dickinson图解

Dickinson图解据Dickinson and Suczek, 1979. Qt, 石英; F, 长石; L, 碎屑 (不包含多晶石英); Qm, 单晶石英; Lt, 碎屑(包含多晶石英); Qp, 多晶石 英(包含燧石); Lv, 火山岩类碎屑; Ls, 沉积岩类碎屑(Liu等, 2005, 2010)

表 1 碎屑锆石微量元素一览表 ${ }^{\text {a) }}$

\begin{tabular}{cccccc}
\hline 样品号 & $\sum \mathrm{REE}(\mathrm{ppm})$ & $(\mathrm{Lu} / \mathrm{Gd})_{\mathrm{N}}$ & $(\mathrm{Yb} / \mathrm{Sm})_{\mathrm{N}}$ & $\delta \mathrm{Ce}$ & $\delta \mathrm{Eu}$ \\
\hline ZD-6 & $263.43 \sim 2161.83$ & $10.59 \sim 64.92$ & $8.72 \sim 124.55$ & $1.39 \sim 78.96$ & $0.03 \sim 1.39$ \\
ZD-106 & $308.67 \sim 4875.58$ & $3.02 \sim 115.24$ & $6.93 \sim 208.85$ & $1.07 \sim 161.52$ & $0.01 \sim 0.77$ \\
ZD-303 & $32.96 \sim 3370.38$ & $2.76 \sim 89.08$ & $10.56 \sim 232.82$ & $1.10 \sim 341.16$ & $0.01 \sim 0.73$ \\
\hline
\end{tabular}

a) 球粒陨石数据自 Sun和McDonough (1989)

约占 $78 \% ; \mathrm{Th} / \mathrm{U}$ 小于 0.1 的颗粒 3 个; 其余颗粒的 $\mathrm{Th} / \mathrm{U} 介$ 于 $0.1 \sim 0.4$ (图7). ZD-303样品中 $\mathrm{Th} / \mathrm{U}$ 大于 0.4 的颗粒有 68 个, 约占 $62 \% ; \mathrm{Th} / \mathrm{U}$ 介于 $0.1 \sim 0.4$ 的颗粒有 22 个, 约占 $20 \%$ (图7).

\section{3 锆石年龄分布}

砂岩锆石样品ZD-6、ZD-106和ZD-303 分别测 试了 120 个颗粒, 除掉少部分因 $\mathrm{Pb}$ 丢失造成年龄不和 谐的颗粒后, 剩余 $\mathrm{U}-\mathrm{Pb}$ 年龄和谐的锆石颗粒分别是
59(ZD-6), 98(ZD-106)和 110(ZD-303)。ZD-6、ZD-106 和ZD-303最年轻的年龄分别是 $(1764 \pm 41) 、(197 \pm 5)$ 、 (214 \pm 3$) \mathrm{Ma}$. 早侏罗世 ZD-6 具有 1764 2496Ma( 峰 值年龄 1787、2077和2440Ma)(图 8a); 中晚侏罗世 ZD-106和 ZD-303 具有相同的年龄谱特征, 分别是 197 291Ma(峰值年龄 $238 \mathrm{Ma}$ )、214 278Ma(峰值年龄 $238 \mathrm{Ma}$ ), 358 484Ma(峰值年龄404Ma)、370 456 Ma(峰 值年龄 418Ma)，645 920Ma( 峰值年龄 $875 \mathrm{Ma}$ )、 $578 \sim 1160 \mathrm{Ma}$ (峰值年龄940Ma), 1390 1991Ma(峰值年 


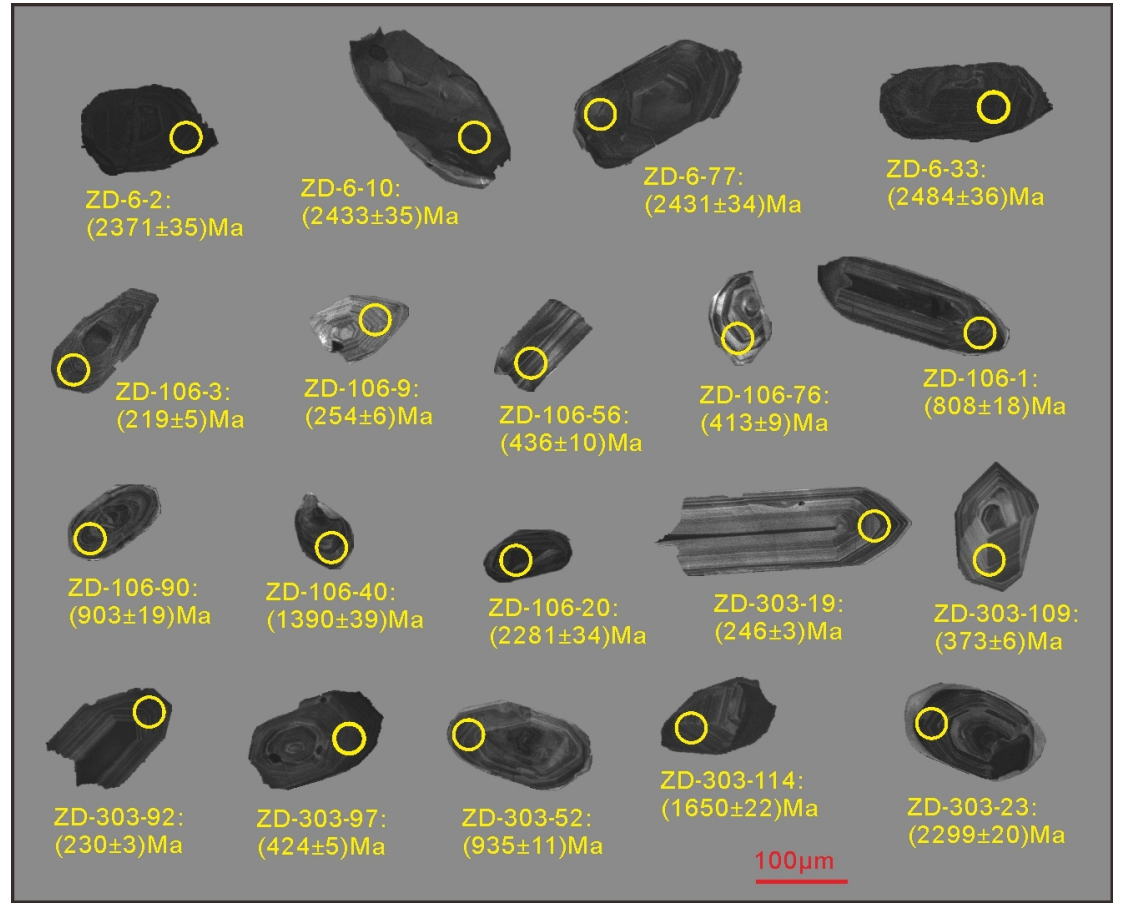

图 5 大煤沟剖面砂岩样品ZD-6、ZD-106和ZD-303碎屑锆石代表性阴极发光图像及其年龄值 样品号后缀数字为测试点序号

龄1875Ma)、1550 1829Ma(峰值年龄1708Ma), 2048 $2484 \mathrm{Ma}$ (峰值年龄 $2272 \mathrm{Ma}$ )、2161 2738Ma(峰值年龄 $2335 \mathrm{Ma})($ 图8b, 8c).

\section{7 碎屑锆石物源分析}

\section{1 样品ZD-6}

早侏罗世砂岩样品ZD-6中, 峰值年龄 1787 和 $2077 \mathrm{Ma}$, 较之 $2440 \mathrm{Ma}$ 不明显. 样品中共有 4 颗锆石的 U-Pb年龄小于 $2000 \mathrm{Ma}$, 其余锆石年龄为2077 2496Ma. 该段年龄范围内大部分碎屑锆石 $(93 \%)$ 具有高的 $\mathrm{Th} / \mathrm{U}$ 值0.34 2.22, 且阴极发光图像显示为较典型的岩浆韵 律环带(图5), 部分锆石具有发亮的变质边.

全吉地块 (欧龙布鲁克地块) 是夹持在柴北缘构 造带和祁连构造带之间的一个北西-南东向的狭长 陆块残片 (王勤燕等, 2008). 该地块由德令哈杂岩、 达肯大阪群、万龙沟岩群及其上部未变质的沉积盖 层全吉群组成. 王勤燕等(2008) 指出达肯大阪岩群 的形成年龄在 $2.43 \sim 2.47 \mathrm{Ga}$ 之间, 并在 $2.43 \mathrm{Ga}$ 发生岩 浆作用及 $1.92 \mathrm{Ga}$ 区域变质作用; Chen等(2012)通过 研究全吉地块中碎屑锆石年龄谱特征指出达肯大阪
岩群约在 $2.47 \mathrm{Ga}$ 发生岩浆作用, 德令哈杂岩形成年龄 为2.11 1.96Ga(表2); Wang等(2015)指出全吉地块结晶 年龄为 $(2272 \pm 15) \mathrm{Ma}$, 并在 $(1928 \pm 11) \mathrm{Ma}$ 遭受了变质作 用; 张海军等(2016)对全吉群红藻山组凝灰岩展开岩 浆锆石LA-ICP-MS U-Pb年龄测试指出其形成年龄为

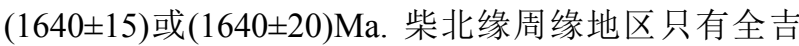
地块大面积出露具有古元古-中元古代年龄信息的地 质体, 结合早侏罗世砂岩样品ZD-6年龄谱出现 1787、 2077和 2440Ma峰值, 指示早侏罗世沉积物主要来自 于全吉地块基底德令哈杂岩、达肯大阪岩群及盖层 全吉群.

\section{2 样品ZD-106和ZD-303}

砂岩样品ZD-106和ZD-303 具有相似的年龄谱 特征，大致具有 5 段年龄范围信息。样品 ZD-106: 197 291Ma(峰值年龄 238Ma), 358 484Ma (峰值年龄 404Ma), 645 920Ma (峰值年龄875Ma), 1390 1991Ma (峰值年龄 $1875 \mathrm{Ma}$ ) 和2048 2484Ma(峰值年龄 $2272 \mathrm{Ma}$ ) (图8b,8c); 样品ZD-303: 214 278Ma (峰值年龄238Ma), 370 456Ma)(峰值年龄 418Ma), 578 1160Ma (峰值年 龄940Ma)，1550 1829Ma (峰值年龄1708Ma)和2161 

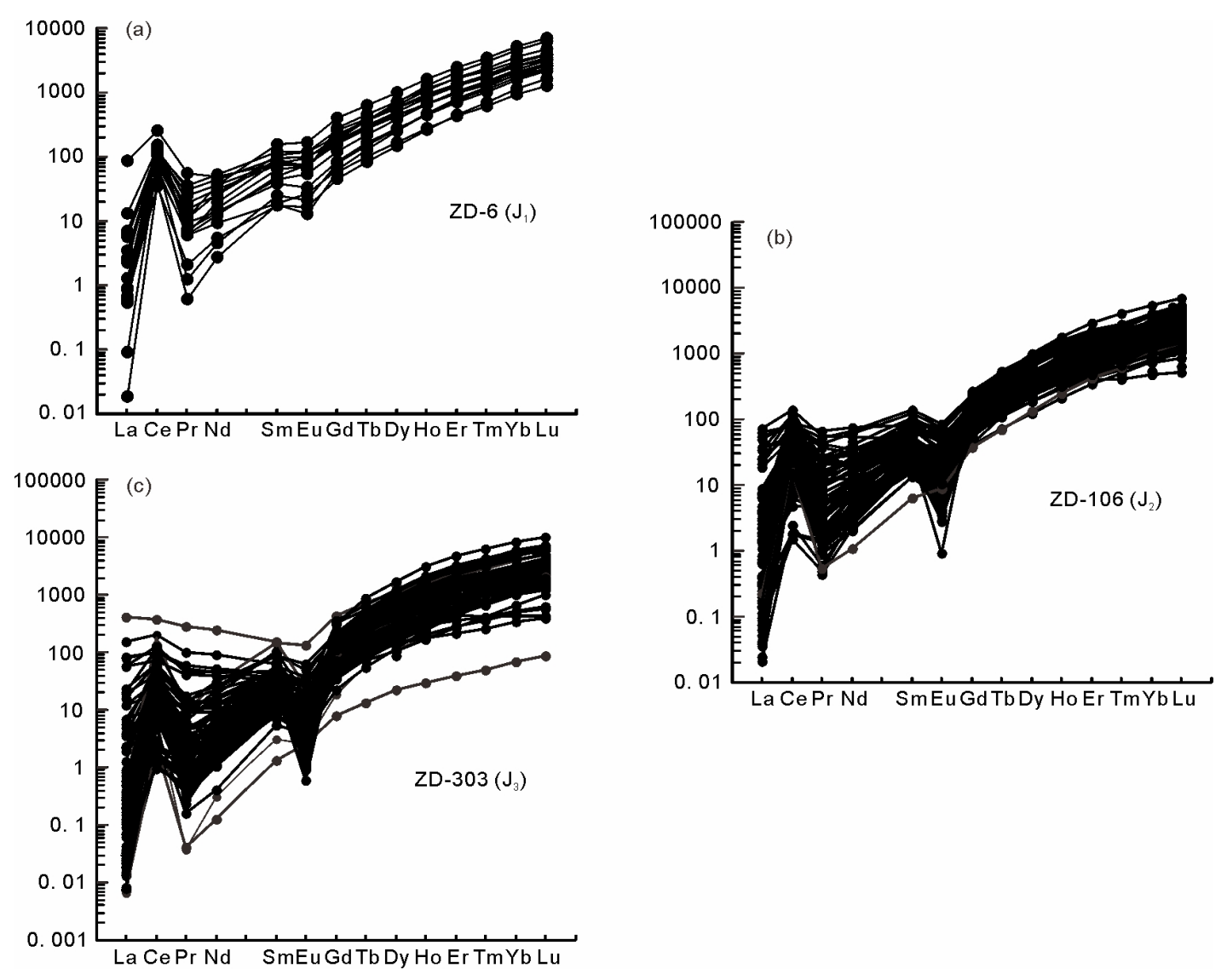

图 6 大煤沟剖面砂岩碎屑锆石稀土元素球粒陨石标准化配分曲线图 球粒陨石数据引自Sun和 McDonough(1989)

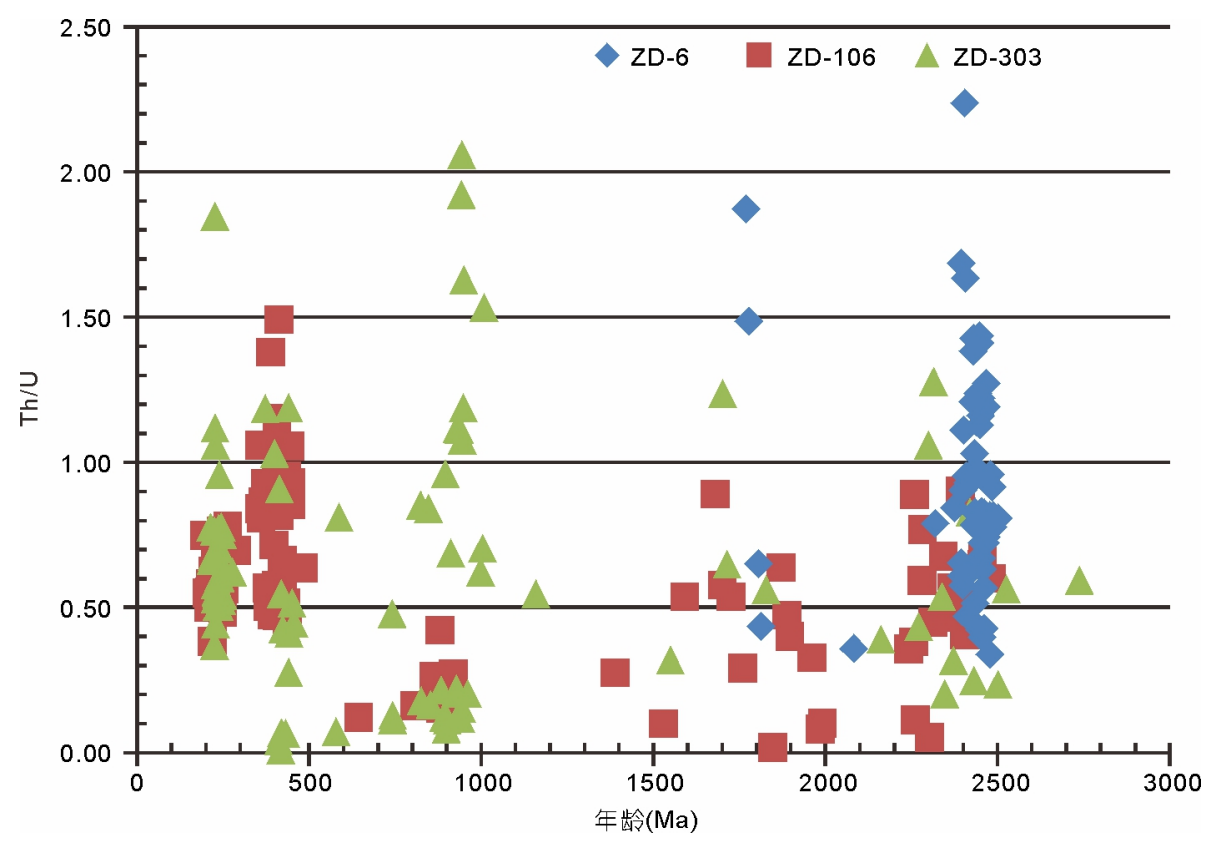

图 7 大煤沟剖面砂岩样品 $\mathbf{T h} / \mathrm{U}$ 比值 
表 2 全吉地块锆石年龄一览表

\begin{tabular}{|c|c|c|c|c|}
\hline 岩性 & 层位 & 年龄 (Ma) & 方法 & 参考文献 \\
\hline $\begin{array}{l}\text { 花岗片麻岩 } \\
\text { 斜长角闪岩 }\end{array}$ & 德令哈杂岩 & $\begin{array}{l}2366 \pm 10 \\
2412 \pm 14\end{array}$ & & 陆松年(2002) \\
\hline 混合岩 & $\begin{array}{l}\text { 德令哈杂岩 } \\
\text { 达肯大阪群 }\end{array}$ & $\begin{array}{l}2467+28 /-26 \\
2474+66 /-52 \\
2471+18 /-16 \\
1924+14 /-15 \\
\end{array}$ & LA-ICP-MS & $\begin{array}{c}\text { 王勤燕等(2008) } \\
\text { Wang等(2008) }\end{array}$ \\
\hline 混合岩 & 全吉地块 & $\begin{array}{l}2470 \pm 19 \\
2202 \pm 26\end{array}$ & LA-ICP-MS & Chen等(2009) \\
\hline 角闪斜长辉石岩 & 德令哈杂岩 & $1913 \pm 38$ & LA-ICP-MS & 张璐等(2011) \\
\hline 碎屑岩 & 全吉地块 & $\begin{array}{c}\sim 2470 \\
1960 \sim 2110\end{array}$ & LA-ICP-MS & Chen等(2012) \\
\hline 花岗质片麻岩 & 全吉地块 & $\begin{array}{l}2381 \pm 41 \\
2392 \pm 25 \\
2367 \pm 12 \\
2372 \pm 22\end{array}$ & LA-ICP-MS & Gong等(2012) \\
\hline 石英砂岩 & 达肯大阪群 & $1950 \sim 2450$ & LA-ICP-MS & 张璐等(2012) \\
\hline 副片麻岩 & 全吉地块 & $2200 \sim 2450$ & LA-ICP-MS & Zhang等(2014) \\
\hline 闪长片麻岩 & 全吉地块 & $\begin{array}{l}2272 \pm 15 \\
1928 \pm 11 \\
\end{array}$ & LA-ICP-MS & Wang等(2015) \\
\hline 凝灰岩 & 达肯大阪群 & $\begin{array}{l}1640 \pm 15 \\
1640 \pm 20\end{array}$ & LA-ICP-MS & 张海军等(2016) \\
\hline
\end{tabular}

$2738 \mathrm{Ma}$ (峰值年龄 2335 和 $2730 \mathrm{Ma}$ ). 中晚侏罗世与早侏 罗世砂岩样品具有明显不同的年龄信息, 指示了沉积 物物源发生了明显变化.

\subsubsection{291 和 214 278Ma}

砂岩样品ZD-106中197 291Ma年龄段范围内锆石 共有21颗, 峰值年龄为238Ma; ZD-303中214 278Ma年 龄段范围内锆石共有36颗, 峰值年龄为 $238 \mathrm{Ma}$. 晚侏罗 世样品在该年龄范围段内的锆石颗粒比中侏罗世明 显增多. 样品ZD-106和ZD-303锆石具有高的 Th/U值, 分别是 $0.38 \sim 0.78$ 和 $0.37 \sim 1.85$. 锆石晶形为长柱体且阴 极发光照片具有典型的岩浆韵律环带(图5), 结合 $\mathrm{Th} / \mathrm{U}$ 值判断该年龄段内碎屑锆石主要来自于物源区岩浆 成因的锆石.

阿尔金山、柴北缘构造带及东昆仑山广泛分布 印支期岩体(表3), 尤其是在阿尔金山及东昆仑山出 露该时期的岩体面积范围更大. 吴才来等(2008)指出 柴北缘西段三岔沟岩体由两期侵入岩组成, 其年龄
分别为 272和 $260 \mathrm{Ma}$; 董增产等 $(2015 \mathrm{a}, 2015 \mathrm{~b})$ 在冷 湖盐场北山地区指出二长花岗岩岩体的形成年龄为 (252 \pm 3$)$ 和(254 \pm 4$) \mathrm{Ma}$; 彭渊等(2016)指出柴北缘宗务隆 造山带晒勒克郭来和察汗诺岩体年龄为(249.2 2 2.6)、 $(242.7 \pm 1.9)$ 和 $(243.5 \pm 2.4) \mathrm{Ma}$. 东昆仑阿斯哈岩体年龄 为 $(238.4 \pm 1.4) \mathrm{Ma}$ (李金超等, 2014)、哈日扎岩体年龄 (234.5 \pm 4.8$) \mathrm{Ma}$ (宋忠宝等, 2013) 以及沟里地区年龄为 (225 1.7) Ma(曹建辉等, 2015) (表3).

从锆石年龄谱特征看, 阿尔金山、柴北缘构造带 及东昆仑山地区都有可能为中晚侏罗世盆地提供沉 积物质. 该年龄段内锆石颗粒多呈棱角状，似乎指示 近距离的搬运过程. 大煤沟剖面中晚侏罗世地层序列 中发育南东-北西和近乎由北向南的两类古水流方向, 似乎也指示这时期盆地沉积物源的多样性及其方向 性. 阿尔金山剥蚀物质顺盆地走向搬运时通过冷湖凹 陷沉积, 因此不易到达冷湖凹陷以东的大柴旦、德令 哈等地区沉积. 大量学者通过构造年代学、沉积学 等方面的研究指出阿尔金山在侏罗纪时期并未隆升 

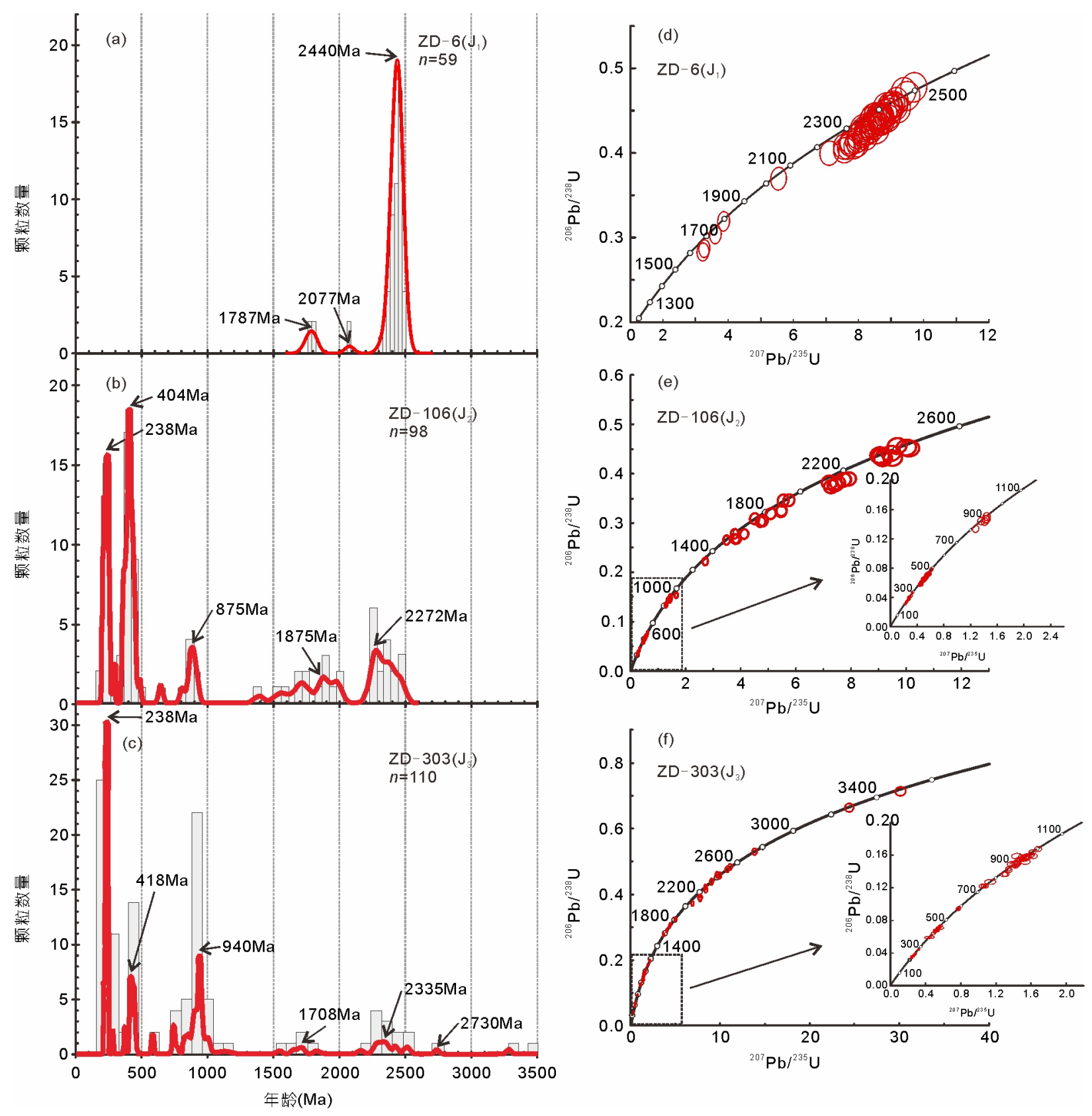

图 8 大煤沟剖面砂岩碎屑锆石年龄谱及其 U-Pb年龄谐和图

(Jolivet等, 2001; Sobel等, 2001); 柴北缘西段与塔里木 盆地东南缘为统一的整体且侏罗系地层序列是可以 划分对比的, 后期的挤压隆升及左行走滑作用分割了 侏罗纪盆地并形成了现今的残余格局(Yuan等, 2003; Yin等, 2007; Cheng等, 2016); 也有学者指出阿尔金山 地区侏罗纪的沉积格局与新生代不一样, 阿尔金山侏 罗纪的沉积相展布格局是从柴达木盆地内部向北东方
向展布延伸至塔里木盆地内部(段宏亮等, 2006, 2007). 埃姆尼克山南部零星发育中侏罗统上部到上侏罗统地 层序列, 说明绿梁山、锡铁山、埃姆尼克山等地区可 能在侏罗纪之后发生隆升作用. 再者, 位于绿梁山、 锡铁山、埃姆尼克山一线南缘的柴南古隆起可能会 阻挡通过横向水流搬运的东昆仑山剥蚀物质. 因此, 印支期的沉积物质可能主要来自柴北缘构造带. 
表 3 柴北缘及其周缘印支期岩体年龄一览表

\begin{tabular}{|c|c|c|c|c|}
\hline 岩性 & 区域 & 年龄 (Ma) & 方法 & 参考文献 \\
\hline 花岗岩 & 柴北缘西段三岔沟 & $\begin{array}{l}271.2 \pm 1.5 \\
260.4 \pm 2.3\end{array}$ & SHRIMP & 吴才来等(2008) \\
\hline 花岗闪长斑岩 & 东昆仑哈日扎 & $234.5 \pm 4.8$ & LA-ICP-MS & 宋忠宝等(2013) \\
\hline 石英闪长岩 & 东昆仑阿斯哈岩体 & $238.4 \pm 1.4$ & LA-ICP-MS & 李金超等(2014) \\
\hline $\begin{array}{c}\text { 闪长岩 } \\
\text { 花岗闪长岩 }\end{array}$ & $\begin{array}{c}\text { 西秦岭西段 } \\
\text { 刚察岩体 }\end{array}$ & $\begin{array}{c}243.8 \sim 242 \\
238 \sim 234 \\
\sim 215\end{array}$ & SHRIMP & 张涛等(2014) \\
\hline $\begin{array}{c}\text { 花岗闪长岩 } \\
\text { 二长花岗岩 } \\
\text { 花岗岩 }\end{array}$ & 东昆仑沟里地区 & $225 \pm 1.7$ & LA-ICP-MS & 曹建辉等(2015) \\
\hline 二长花岗岩 & 冷湖盐场北山 & $252 \pm 3$ & LA-ICP-MS & 董增产等(2015a) \\
\hline 黑云母二长花岗岩 & 冷湖盐场北山 & $254 \pm 4$ & LA-ICP-MS & 董增产等(2015b) \\
\hline 花岗闪长岩 & $\begin{array}{c}\text { 宗务隆构造带 } \\
\text { 晒勒克郭来 } \\
\text { 察汗诺岩体 }\end{array}$ & $\begin{array}{l}249.2 \pm 2.6 \\
242.7 \pm 1.9 \\
243.5 \pm 2.4\end{array}$ & SHRIMP & 彭渊等(2016) \\
\hline 二长花岗岩 & 南祁连化石沟 & $252 \pm 2.1$ & LA-ICP-MS & 胡万龙等(2016) \\
\hline
\end{tabular}

\subsubsection{484 和 $370 \sim 456 \mathrm{Ma}$}

砂岩样品ZD-106中358 484Ma年龄段范围内锆石 共有 33 颗, 峰值年龄为 $404 \mathrm{Ma} ; \mathrm{ZD}-303$ 中 $370 \sim 456 \mathrm{Ma}$ 年龄段范围内锆石共有 16 颗, 峰值年龄为 $418 \mathrm{Ma}$. 样品ZD-106和ZD-303锆石具有高的 Th/U值, 分别是 $0.45 \sim 1.49$ 和 $0.01 \sim 1.19$. 阴极发光照片显示部分锆石具 有变质成因的生长边(图5), 结合 $\mathrm{Th} / \mathrm{U}$ 值判断该年龄段 内碎屑锆石既有岩浆成因也有部分变质成因.

柴北缘构造带(高压-超高压变质带)位于祁连地 块和柴达木地块结合部位, 经过都兰野马滩、沙柳 河、德令哈、全吉山、锡铁山、达肯大阪山直至小 赛什腾山, 是一条典型的早古生代造山带(Song 等, 2006, 2007). 该变质带中段锡铁山地区峰期变质时间 为 488 486Ma (Zhang等, 2005)并约在 430Ma形成花岗 岩; 绿梁山地区峰期变质时间为 435 414Ma(Song 等, 2005). 吴才来等 $(2004,2007,2008,2014)$ 、卢欣祥等 (2007)、孟繁聪和张建新(2008)、宋述光等(2011)、朱 小辉等(2014)、孙娇鹏等(2015)、Martinson等(2006)、 Song等(2006, 2014a, 2014b)、Wang等(2014), Zhang等 $(2008,2010,2011)$ 和Xu等(2016)在柴北缘赛什腾山、 团鱼山、嗷唠山、绿梁山、锡铁山、大柴旦、宗务隆 构造带、都兰及祁连山地区对早古生代榴辉岩、花 岗岩、二长花岗岩、石英闪长岩、花岗闪长岩、片
麻岩及后期侵入的岩体进行LA-ICP-MS或者SHRIMP 年代学测试, 得到了大量U-Pb年龄信息(表4). 同印支 期的沉积物质来源分析一样的道理, 早古生代及海西 期早期的沉积物质可能来自于柴北缘构造带、全吉 地块及祁连地块.

\subsubsection{920 和 $578 \sim 1160 \mathrm{Ma}$}

砂岩样品 ZD-106 中 645 920Ma年龄段范围内 锆石共有 8 颗, 峰值年龄为 $875 \mathrm{Ma}$; 其中 6 颗年龄为 864 920Ma, 为形成于新元古代早期的锆石. ZD-303 中 578 1160Ma年龄段范围内锆石共有 40 颗, 峰值年 龄为 $940 \mathrm{Ma}$; 其中 2 颗锆石年龄为 578 和 $588 \mathrm{Ma}, 34$ 颗锆 石年龄为 742 999Ma, 多数为新元古代时期的锆石. 样品ZD-106和ZD-303锆石的 $\mathrm{Th} / \mathrm{U}$ 值分别是 0.12 0.42 和0.07 2.06. 阴极发光照片显示该年龄段内锆石可能 主要为变质成因.

雍拥等(2008)运用LA-ICP-MS 法在中祁连东段 地区得出花岗岩锆石年龄为 $(853 \pm 2.3)$ 、( $888 \pm 2.5)$ 和 (846 \pm 2$) \mathrm{Ma}$; 李猛等(2015)运用LA-ICP-MS法在祁连山 西段吊大阪得出花岗质片麻岩年龄为 $(736 \pm 4.7) \mathrm{Ma}$ 等; 陆松年(2002)在大柴旦、绿梁山和锡铁山地区 得出花岗岩和闪长岩年龄为 $(1020 \pm 41) 、(803 \pm 7)$ 和 (744 \pm 28$) \mathrm{Ma}$; Song等 $(2010,2012)$ 在鱼卡、锡铁山和 
钱涛等: 柴达木盆地北缘侏罗纪沉积物源分析: 地层序列及LA-ICP-MS年代学信息

表 4 柴达木盆地北缘早古生代岩体年龄一览表

\begin{tabular}{|c|c|c|c|c|}
\hline 岩性 & 区域 & 年龄(Ma) & 方法 & 参考文献 \\
\hline $\begin{array}{c}\text { 石英二长闪长岩 } \\
\text { 花岗闪长岩 }\end{array}$ & 祁连山南缘 & $\sim 473 、 \sim 446 、 \sim 397$ & SHRIMP & 吴才来等(2004) \\
\hline 环斑花岗岩 & 塔塔楞河地区 & $440 \pm 14$ & SHRIMP & 卢欣祥等(2007) \\
\hline 花岗岩 & 大柴旦地区 & $\begin{array}{c}446.3 \pm 3.9 、 408.6 \pm 4.4 \\
403.3 \pm 3.8 、 401.8 \pm 3 \\
374.5 \pm 1.6 、 372.0 \pm 2.1\end{array}$ & SHRIMP & 吴才来等(2007) \\
\hline 花岗岩 & 绿梁山 & $430 \pm 8$ & SHRIMP & 孟繁聪和张建新(2008) \\
\hline $\begin{array}{c}\text { 花岗岩 } \\
\text { 石英闪长岩 }\end{array}$ & $\begin{array}{l}\text { 赛什腾山、团鱼山 } \\
\text { 三岔沟、嗷唠河 }\end{array}$ & $\begin{array}{ll}465.4 \pm 3.5 、 & 469.7 \pm 4.6 \\
443.5 \pm 3.6 、 & 372.1 \pm 2.6 \\
271.2 \pm 1.5 、 & 260.4 \pm 2.3\end{array}$ & LA-ICP-MS & 吴才来等(2008) \\
\hline 榴辉岩 & 锡铁山 & $433 \pm 3$ & SIMS & 宋述光等(2011) \\
\hline 巴嘎德尔基岩 & 中祁连山西段 & $462.9 \pm 1.4$ & LA-ICP-MS & 齐瑞荣(2012) \\
\hline 北大河岩群 & 中祁连西段 & $444 \pm 6.9$ & LA-ICP-MS & 彭岩等(2014) \\
\hline 花岗岩 & $\begin{array}{c}\text { 野马滩东 } \\
\text { 巴立给哈滩西 } \\
\text { 水文站北 } \\
\text { 察察公麻 }\end{array}$ & $\begin{array}{c}406.6 \pm 3.5 、 407.3 \pm 4.3 \\
397 \pm 6 、 404.5 \pm 4.0 \\
397.0 \pm 3.7 、 380.5 \pm 5.0 \\
380.5 \pm 3.6 、 372.5 \pm 2.8 \\
\end{array}$ & SHRIMP & 吴才来等(2014) \\
\hline 花岗岩 & 铁石观岩体 & $422.0 \pm 6.4$ & LA-ICP-MS & 周宾等(2014) \\
\hline 变辉长岩 & 绿梁山大平沟 & $535 \pm 2 、 397 \pm 6 、 493 \pm 3$ & LA-ICP-MS & 朱小辉等(2014) \\
\hline 野马山岩基 & 中祁连西段 & $469 \pm 1.3 、 450.0 \pm 1.0$ & LA-ICP-MS & 黄增保等(2015) \\
\hline 变质岩 & 宗务隆构造带 & $\begin{array}{c}437.8 \pm 2.7 、 440 \pm 3 \\
433.2 \pm 3.6 、 497.1 \pm 3.5 \\
464.1 \pm 4.2\end{array}$ & SHRIMP & 孙娇鹏等(2015) \\
\hline $\begin{array}{c}\text { 榴辉岩 } \\
\text { 富含石榴石榴辉岩 }\end{array}$ & 都兰 & $\begin{array}{c}448.9 \pm 2.2 、 422.0 \pm 4.3 \\
432.5 \pm 4.7 \\
\end{array}$ & SHRIMP & Mattinson 等(2006) \\
\hline $\begin{array}{l}\text { 榴辉岩 } \\
\text { 副片麻岩 }\end{array}$ & 都兰、鱼卡 & $\begin{array}{cc}464 \pm 5.5 、 & 426 \pm 12 \\
423 \pm 6 、 & 403 \pm 9 \\
\end{array}$ & SHRIMP & Song等(2006) \\
\hline 榴辉岩 & 都兰 & $445 \pm 7$ & SHRIMP & Zhang等(2008) \\
\hline 榴辉岩 & 都兰 & $438 \pm 2$ & SHRIMP & Zhang 等 (2010) \\
\hline 榴辉岩 & 锡铁山 & $439 \pm 8 、 461 \pm 4$ & SHRIMP & Zhang 等(2011) \\
\hline $\begin{array}{l}\text { 石英闪长岩 } \\
\text { 英云闪长岩 }\end{array}$ & 都兰 & $\begin{array}{cl}423 \pm 4 、 & 427 \pm 3 、 431 \pm 3 \\
& 410 \pm 4\end{array}$ & $\begin{array}{l}\text { SHRIMP } \\
\text { LA-ICP-MS }\end{array}$ & Song等 (2014a) \\
\hline $\begin{array}{l}\text { 榴辉岩 } \\
\text { 变泥质岩 }\end{array}$ & 都兰、鱼卡 & $\begin{array}{c}425 \pm 8 、 450 \pm 11 、 462 \pm 13 \\
426.5 \pm 2.4\end{array}$ & $\begin{array}{c}\text { SHRIMP } \\
\text { LA-ICP-MS }\end{array}$ & Song等 (2014b) \\
\hline $\begin{array}{c}\text { 二云花岗岩 } \\
\text { 石英闪长岩 } \\
\text { 花岗闪长岩 } \\
\text { 黑云母二长花岗岩 }\end{array}$ & $\begin{array}{l}\text { 野马滩 } \\
\text { 沙柳河 }\end{array}$ & 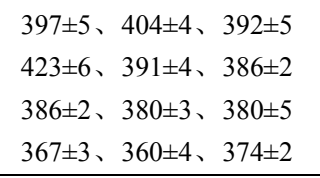 & ICP-MS & Wang等 (2014) \\
\hline 榴辉岩 & 嗷唠山 & $433 \pm 18 、 439 \pm 4$ & LA-ICP-MS & Xu 等 (2016) \\
\hline
\end{tabular}

都兰地区出露的榴辉岩和片麻岩中运用SHRIMP和

LA-ICPMS方法得出U-Pb年龄为 $(847 \pm 10) 、(847 \pm 44)$ 、
$(907 \pm 18) 、(932 \pm 18) 、(951 \pm 24) 、(942 \pm 16) 、(976 \pm 19)$ 和(941 \pm 21$) \mathrm{Ma} ; Y u$ 等(2013)在都兰地区得到榴辉岩、 
片岩和片麻岩 $\mathrm{U}-\mathrm{Pb}$ 年龄为 $(664 \pm 9.3)$ 、(874 \pm 9.9$)$ 、 (985 \pm 22$)$ 和 $(923 \pm 12) \mathrm{Ma} ; \mathrm{Xu}$ 等 $(2015,2016)$ 在祁连山 和柴北缘嗷唠山地区得出玄武岩、火山碎屑岩和榴 辉岩 $U-P b$ 年龄分别是 $(600 \pm 7) 、(583 \pm 3) 、(845 \pm 8)$ 和 $(851 \pm 5) \mathrm{Ma}$ (表 5$)$. 大量参考文献数据显示新元古代年 龄主要分布在祁连山和柴北缘构造带两个地区. 万 渝生等(2003)指出由壳源花岗质岩石和变质岩系组 成的中祁连地体前寒武变质基底主要形成于晋宁期 800 1000Ma; 柴北缘变质基底壳源花岗岩也形成于晋 宁期, 表明祁连造山带和柴北缘属同一基底, 具有相 同或类似的早期演化历史. Song等(2010)在柴北缘超 高压变质带中通过榴辉岩样品U-Pb年龄指出经历了 $\sim 850 \mathrm{Ma}$ 岩浆结晶作用和 $433 \mathrm{Ma}$ 变质作用. 柴达木地 块可能是具有被动大陆边缘性质的Rodinia超大陆的 一个碎块, 在早古生代时期由于大洋岩石圈的俯冲过 程被拖拽至地幔深部. Song等(2012)指出柴北缘构造 带经历了新元古代格林威尔造山作用和早古生代加 里东造山作用. 响应于Rodinia超大陆在新元古代发生 的裂解作用, 祁连地块和柴北缘遭受了岩浆作用. 侏 罗纪时期祁连山和柴北缘发生的构造活动使古老地
体出露到地表, 后期遭受风化剥蚀作用提供了沉积物 质来源. 从区域演化史和锆石 U-Pb年龄分布范围分 析, 祁连山构造带和柴北缘构造带为侏罗纪柴达木盆 地提供了新元古代碎屑物质。

\subsubsection{1991 和 1550 1829Ma}

样品ZD-106中1390 1991Ma年龄段范围内锆石共 有 15 颗, 约占总数的 $19 \%$, 峰值年龄为 $1875 \mathrm{Ma}$. 其中 3 颗年龄为 $1390 、 1531$ 和 $1592 \mathrm{Ma}$, 约占总数的 $3 \%$, 为 形成于中元古代的锆石. ZD-303中1550 1829Ma年龄 段范围内锆石共有 5 颗, 约占总数的 $4 \%$, 峰值年龄为 1708Ma. ZD-106 Th/U值范围是0.02 0.89, 仅 1颗锆石 $\mathrm{Th} / \mathrm{U}$ 值小于 $0.1 ; \mathrm{ZD}-303 \mathrm{Th} / \mathrm{U}$ 值为 $0.32 \sim 1.23$. 结合阴极 发光图像具有岩浆韵律环带特征(图5), 推测该年龄段 内主要为岩浆成因锆石, 并且后期遭受了一定程度的 变质作用. 样品中出现极少数中元古代年龄信息锆石, 两个峰值年龄 1875 和 $1708 \mathrm{Ma}$ 均形成于古元古代早 期. 表2显示了全吉地块大面积出露古元古-中元古代 年龄地质体, 结合样品锆石 U-Pb年龄信息和潜在源区 地质体年龄分布特征分析指出全吉地块为侏罗纪柴

表 5 柴达木盆地北缘新元古代岩体年龄一览表

\begin{tabular}{|c|c|c|c|c|}
\hline 岩性 & 区域 & 年龄(Ma) & 方法 & 参考文献 \\
\hline $\begin{array}{c}\text { 花岗质片麻岩 } \\
\text { 糜棱岩化花岗质片麻岩 }\end{array}$ & 祁连山基底 & $\begin{array}{c}930 \pm 8 、 918 \pm 14 \\
790 \pm 12\end{array}$ & SHRIMP & Tung 等(2007) \\
\hline 花岗岩 & 中祁连东段 & $\begin{array}{c}853 \pm 2.3 、 888 \pm 2.5 \\
846 \pm 2 、 756 \pm 2.2\end{array}$ & LA-ICP-MS & 雍拥等(2008) \\
\hline 花岗质片麻岩 & 祁连山西段 & $736 \pm 4.7$ & LA-ICP-MS & 李猛等(2015) \\
\hline $\begin{array}{c}\text { 奥长花岗岩、花岗闪长岩 } \\
\text { 钾质花岗岩 } \\
\end{array}$ & $\begin{array}{c}\text { 大柴旦鱼卡河 } \\
\text { 绿梁山、锡铁山 }\end{array}$ & $\begin{array}{c}1020 \pm 41 、 803 \pm 7 \\
744 \pm 28 \\
\end{array}$ & & 陆松年等(2002) \\
\hline $\begin{array}{l}\text { 黑云变粒岩-片麻岩 } \\
\text { 白云母花岗岩 }\end{array}$ & $\begin{array}{l}\text { 祁连马衔山 } \\
\text { 柴北缘 }\end{array}$ & $\begin{array}{c}940 \pm 30 、 1030 \pm 40 、 \\
1020 \pm 40\end{array}$ & TIMS & 万渝生等(2003) \\
\hline 榴辉岩 & 鱼卡 & $847 \pm 10 、 847 \pm 44$ & SHRIMP & Song等(2010) \\
\hline $\begin{array}{c}\text { 片麻岩、花岗质片麻岩 } \\
\text { 石榴石-蓝晶石片麻岩 }\end{array}$ & $\begin{array}{l}\text { 都兰 } \\
\text { 锡铁山 } \\
\text { 鱼卡 } \\
\text { 锡铁山 }\end{array}$ & $\begin{array}{c}907 \pm 18 、 932 \pm 18 \\
951 \pm 24 、 942 \pm 16 \\
976 \pm 19 、 941 \pm 21 \\
916 \pm 7 、 928 \pm 12\end{array}$ & LA-ICPMS & Song等 (2012) \\
\hline $\begin{array}{c}\text { 榴辉岩、云母片岩 } \\
\text { 正片麻岩 }\end{array}$ & 都兰 & $\begin{array}{cc}664 \pm 9.3 、 874 \pm 9.9 \\
985 \pm 22 、 923 \pm 12 \\
\end{array}$ & $\begin{array}{l}\text { LA-ICPMS } \\
\text { SHRIMP }\end{array}$ & Yu等(2013) \\
\hline 玄武岩、火山碎屑岩 & 祁连山 & $600 \pm 7 、 583 \pm 3$ & SIMS & Xu等(2015) \\
\hline 榴辉岩 & 嗷唠山 & $\begin{array}{c}845 \pm 8 、 851 \pm 5 \\
846 \pm 6 、 803 \pm 38 \\
832 \pm 9\end{array}$ & LA-ICP-MS & Xu等(2016) \\
\hline
\end{tabular}


达木盆地提供了古元古-中元古代年龄碎屑物质.

\subsubsection{248 和 2161 2738Ma}

样品ZD-106中2048 2484 Ma年龄段范围内锆石共 有 21 颗, 峰值年龄为 $2272 \mathrm{Ma}$, 约占总数的 $21 \%$. ZD-303 中 $2161 \sim 2738 \mathrm{Ma}$ 年龄段范围内锆石共有 13 颗, 峰值年 龄为 $2335 \mathrm{Ma}$, 约占总数的 $11 \%$. 样品ZD-106和ZD-303 锆石 $\mathrm{Th} / \mathrm{U}$ 值分别是: $0.05 \sim 0.90$ 和 $0.20 \sim 1.28$.

样品ZD-106和ZD-303年龄谱中出现的峰值 2272 和 $2335 \mathrm{Ma}$, 与样品ZD-6年龄峰值 2077 和 $2440 \mathrm{Ma}$ 一 致, 均形成于古元古代晚期. 与古元古代早期和中元 古代的锆石U-Pb年龄信息分析道理一样, 指示了全吉 地块基底德令哈杂岩和达肯大阪岩群为柴达木盆地 提供了中晚侏罗世沉积物质.

\section{8 讨论}

柴达木盆地是一个典型的陆内盆地, 以沉积了巨 厚的中新生代地层为显著特征. 侏罗纪地层沉积之后, 遭受了多次构造叠加改造作用, 现今呈现被改造后的 残余面貌. 柴北缘大煤沟剖面发育具有辫状河、滨浅 湖、辫状河三角洲沉积特征的厚层地层序列. 边缘相 的缺乏似乎指示了大煤沟地区或者柴北缘构造带并不 是柴达木盆地侏罗纪原型盆地的北部边界. 砂岩体中 发育的板状交错层理-槽状交错层理经古水流方向校 正指示了盆地中发育两类古水流(纵向水流和横向水 流), 暗示侏罗纪沉积物质可能来自于柴达木盆地北部 及南部的地质体. 通过砂岩碎屑组分投图发现, 沉积 物质主要来自再旋回造山带及少部分来自于碰撞缝合 带、褶皱-逆冲带、岩浆弧造山带和大陆地块, 指示侏 罗系沉积物质可能来源于柴北缘构造带(高压-超高压 变质带)、全吉地块、祁连地块、阿尔金山和东昆仑 山. 从锆石 $\mathrm{U}-\mathrm{Pb}$ 年龄谱特征匹配角度分析, 阿尔金山 和东昆仑山可能为侏罗系地层序列提供沉积物质. 然 而, 从下面几种情况判断, 阿尔金山构造带和东昆仑山 构造带可能不会为柴达木盆地提供侏罗纪碎屑物质: (1) 构造年代学研究成果表明, 阿尔金山在侏罗纪时期 并未隆升(Jolivet等, 2001; Sobel等, 2001). (2) 现今被 阿尔金山分隔开的柴达木盆地和塔里木盆地在侏罗 纪时期是连通的统一整体(Yuan等, 2003; Yin等, 2007; Cheng等, 2016)且阿尔金山侏罗纪地层序列的沉积相 展布格局是从柴达木盆地内部向北东方向展布延伸
至塔里木盆地内部 (段宏亮等, 2006, 2007). (3)阿尔金 山和柴北缘构造带交截部位冷湖凹陷会阻挡碎屑物 质通过, 从而不能达到柴北缘东段地区沉积. (4)研究 成果指示了东昆仑山开始活动时间为 $30 \sim 20 \mathrm{Ma}$ (Zhang 等, 2004; Duvall 等, 2013; Cheng 等, 2014)或始新世-渐 新世到中新世, 甚至晚渐新世-中中新世时期(Yuan 等, 2003; Yin 等, 2007; Duvall 等, 2013; Mao等, 2014). (5) 东昆仑山前乌图美仁地区零星出露侏罗纪地层, 初步 判断为一套具有滨浅湖特征的沉积地层序列(未发表 资料). 因此, 东昆仑山可能在侏罗纪时期处于接受沉 积物质的状态, 不能为柴达木盆地提供碎屑物质. (6) 位于绿梁山、锡铁山一带南缘的柴南古隆起可能会 阻挡东昆仑山的剥蚀物质, 从而不能通过盆地横向水 流搬运至盆地北缘沉积.

三个侏罗系砂岩样品LA-ICP-MS锆石U-Pb年龄 显示: 早侏罗世样品年龄谱具有古元古代单一峰值特 征; 中晚侏罗世样品年龄谱具有多峰分段式特征, 包 括三叠纪、志留纪-泥盆纪、新元古代、古元古代早 期和古元古代晚期峰值年龄. 于早侏罗世相比, 中晚 侏罗世物源区扩大至祁连山、柴北缘地区, 同时全吉 地块也在持续遭受剥蚀. 早侏罗世全吉地块强烈抬升 遭受剥蚀作用, 为盆地提供了大量的碎屑物质; 中晚 侏罗世柴北缘构造带、祁连山发生隆升构造作用, 与 全吉地块一起为盆地提供沉积物质. 碎屑锆石年龄谱 从古元古代单一峰值到后期多峰值的变化表明, 早中 侏罗世之交柴北缘地区经历的强烈构造作用导致沉 积物源区发生了明显变化. 虽然没有在侏罗系的野外 露头找到这一强烈运动所产生的角度不整合接触关 系, 但早中侏罗世沉积物源区的明显变化正是这一运 动的“沉积物质表现”. 正如Ritts和Biffi(2001)推测, 中 侏罗世地层序列之间呈现由于挤压构造运动而产生 的角度不整合接触关系. 侏罗纪全吉地块的抬升、柴 北缘高压-超高压变质带的折返剥露、祁连山的活化 及柴达木盆地的沉降沉积, 这一早中侏罗世之交发生 的导致沉积物源区明显变化的强烈陆内变形构造作 用可能是燕山运动在柴达木盆地地区的表现.

\section{9 结论}

(1) 柴北缘以大煤沟地区出露侏罗系地层最为完 整. 整个侏罗系发育具有辫状河、滨浅湖和辫状河三 角洲沉积体系特征的地层序列. 
(2) 研究区碎屑锆石 LA-ICP-MS U-Pb 测年结 果显示, 早侏罗世小煤沟组具有古元古代单峰年 龄谱特征： 1787、 2077和 2440Ma; 中晚侏罗世 具有相同的年龄谱特征, 分别可划分为 5 个年龄区 间：197 291、214 278Ma，358 484、370 456Ma, 645 920、578 1160Ma, 1390 1991、1550 1829Ma, 2048 2484、2161 2738Ma.

(3) 碎屑组分、古水流及碎屑锆石物源综合分析 结果表明, 柴北缘侏罗纪沉积物质来自柴北缘构造带 (高压-超高压变质带)、全吉地块、祁连山. 中晚侏罗 世相比于早侏罗世沉积物源区发生了明显的变化, 由 早期的全吉地块扩大至柴北缘构造带和祁连山地区.

（4）早中侏罗世之交发生的强烈陆内变形作用导 致了沉积物源区的显著变化, 而这一显著变化可能是 侏罗纪时期构造运动(燕山运动)在柴达木盆地的沉积 物质表现.

致谢东华理工大学许欢, 昆明理工大学江小均、严 清高, 兰州大学盘法侦参加了部分野外工作; 中国石油大 学(北京)刘艳姣参加了碎屑锆石 LA-ICP-MS U-Pb年龄测 试实验; 西北大学董云鹏教授和暑名专家提出了重要的 修改意见; 在此向他们表示衷心的感谢.

\section{参考文献}

曹国强, 陈世悦, 徐凤银, 彭德华, 袁文芳. 2005. 柴达木盆地西 部中-新生代沉积构造演化. 中国地质, 32: 33-40

曹建辉, 袁万明, 郝娜娜, 冯云否, 陈小宁, 段宏伟, 程学芹. 2015. 东 昆仑沟里地区花岗岩年代学、岩石地球化学及其地球动力学意 义. 地质科技情报, 34: 42-51

曾联波, 金之钧, 张明利, 汤良杰, 由福报, 雷兵足. 2002. 柴达木盆 地侏罗纪盆地性质及其演化特征. 沉积学报, 20: 288-292

董增产, 幸平阳, 陈锐明, 查显锋, 张海迪. 2015a. 柴北缘西端盐场 北山二长花岗岩年代学、地球化学及其Hf同位素特征. 地球科 学——国地质大学学报, 40: 130-144

董增产, 杨成, 幸平阳, 王红, 查显锋, 陈锐明, 张海迪. 2015b. 青海 冷湖盐城北山黑云母二长花岗岩年代学、地球化学及其地质意 义. 大地构造与成矿学, 39: 167-178

段宏亮, 钟建华, 马锋, 张跃中, 李勇, 温志峰. 2007. 柴达木盆地西 部中生界原型盆地及其演化. 地球学报, 28: 356-368

段宏亮, 钟建华, 马锋, 张跃中, 李勇. 2006. 柴西阿尔金山前中、下 侏罗统展布及油气勘探方向. 中国石油大学学报(自然科学版), 30: $13-18$

付玲, 关平, 赵为永, 王牧, 张英, 卢静文. 2013. 柴达木盆地古近系
路乐河组重矿物特征与物源分析. 岩石学报, 29: 2867-2875

胡万龙, 贾志强, 王金荣, 侯克选, 王淑华. 2016. 南祁连化石沟花 岗岩年代学、地球化学特征及其构造意义. 高校地质学报, 22: 242-253

黄增保, 郑建平, 李葆华, 魏志军, 漆玮, 陈旭. 2015. 中祁连西段 野马山岩基年代学、地球化学特征及地质意义. 中国地质, 42: 406-420

蒋荣宝, 陈宣华, 党玉琪, 尹安, 汪立群, 蒋武明, 万景林, 李丽, 王小 凤. 2008. 柴达木盆地东部中新生代两期逆冲断层作用的FT定 年. 地球物理学报, 51: 116-124

金振奎, 齐聪伟, 薛建勤, 王春生, 范小娜. 2006. 柴达木盆地北缘侏 罗系沉积相. 古地理学报, 8: 199-210

李金超, 贾群子, 杜玮, 栗亚芝, 孔会磊, 南卡俄吾, 杨宝荣. 2014. 东 昆仑东段阿斯哈矿床石英闪长岩LA-ICP-MS锆石U-Pb定年及岩 石地球化学特征. 吉林大学学报(地球科学版), 44: 1188-1199

李俊武, 代廷勇, 李风杰, 杨承锦, 杨豫川. 2015a. 柴达木盆地鄂博 梁地区古近系沉积物源方向分析. 沉积学报, 33: 649-658

李俊武, 杨承锦, 李风杰, 吴永良, 代廷勇. 2015b. 柴达木盆地鄂博 梁地区新近系沉积物源分析. 古地理学报, 17: 186-197

李林林, 郭召杰, 管树巍, 周苏平, 王明振, 房亚男, 张晨晨. 2015. 柴 达木盆地西南缘新生代碎屑重矿物组合特征及其古地理演化. 中国科学: 地球科学, 45: 780-798

李猛, 王超, 李荣社, 彭岩. 2015. 祁连山西段新元古代晚期花岗质片 麻岩成因及LA-ICP-MS铅石U-Pb定年. 地质通报, 34: 1438-1446 李伟, 刘宝珺, 白淑艳. 2002. 柴达木盆地侏罗系地层沉积大迁移及 成因分析. 石油学报, 23: 16-19

刘云生, 郭战峰, 梁西文, 杨振武. 2006. 中上扬子地区晚三叠世-侏 罗纪砂岩构造意义及盆山耦合关系. 石油实验地质, 28: 201-205 卢欣祥, 孙延贵, 张雪亭, 肖庆辉, 王晓霞, 尉向东, 谷德敏. 2007. 柴 达木盆地北缘塔塔楞环斑花岗岩的SHRIMP年龄. 地质学报, 81 : 626-634

陆松年. 2002. 青藏高原北部寒武纪地质初探. 北京: 地质出版社. $1-125$

孟繁聪, 张建新. 2008. 柴北缘绿梁山早古生代花岗岩浆作用与高 温变质作用的同时性. 岩石学报, 24: 1585-1594

彭岩, 李荣社, 计文化, 王超, 李猛, 张辉善, 吴中楠. 2014. 中祁连西 段北大河岩群中早古生代火山碎屑岩的识别——来自锆石U-Pb 年代学的证据. 西北地质, 47: 178-186

彭渊, 马寅生, 刘成林, 李宗星, 孙娇鹏, 郡鹏程. 2016. 柴北缘宗务 隆构造带印支期花岗闪长岩地质特征及其构造意义. 地学前缘, 23: $206-221$

齐瑞荣. 2012. 中祁连西段巴嘎德尔基岩体LA-ICP-MS锆石U-Pb年 龄及地质意义. 沉积与特提斯地质, 32: 86-93

邵龙义, 李猛, 李永红, 张云鹏, 鲁静, 张文龙, 田政, 文怀军. 2014 . 柴达木盆地北缘侏罗系页岩气地质特征及控制因素. 地学前缘, 21: $311-322$ 
宋述光, 张聪, 李献华, 张立飞. 2011. 柴北缘超高压带中锡铁山榴 辉岩的变质时代. 岩石学报, 27: 1191-1197

宋忠宝, 张雨莲, 陈向阳, 江否, 李东生, 舒晓峰, 栗亚芝, 李金超, 孔 会磊. 2013. 东昆仑哈日扎含矿花岗闪长斑岩LA-ICP-MS 锆石 U-Pb定年及地质意义. 矿床地质, 32: 157-168

孙娇鹏, 陈世悦, 彭渊, 邵鹏程, 马帅, 刘金. 2015. 柴达木盆地北缘 宗务隆构造带早古生代锆石SHRIMP年龄的测定及其地质意义. 地质论评, 61: 743-751

汤良杰, 金之钧, 张明利, 刘池阳, 吴汉宁, 由福报, 张兵山. 2000. 柴 达木盆地构造古地理分析. 地学前缘, 7: 421-429

万渝生, 许志琴, 杨经绥, 张建新. 2003. 祁连造山带及其邻区前寒 武纪深变质基底的时代及组成. 地球学报, 2: 319-324

王勤燕, 陈能松, 李晓彦, 郝爽, 陈海红. 2008. 全吉地块基底达肯 大阪岩群和热事件的LA-ICPMS 锆石U-Pb定年. 科学通报, 53: 1693-1701

吴才来, 郜源红, 李兆丽, 雷敏, 秦海鹏, 李名则, 刘春花, Frost R B, Robinson P T, Wooden J L. 2014. 都兰花岗岩锆石SHRIMP 定年 及柴北缘超高压带花岗岩年代学格架. 中国科学: 地球科学, 44: 2142-2159

吴才来, 郜源红, 吴锁平, 陈其龙, Wooden J L, Mazadab F K, Mattinson C. 2008. 柴北缘西段花岗岩锆石SHRIMP U-Pb定年及其岩石地 球化学特征. 中国科学: 地球科学, 38: 930-949

吴才来, 郜源红, 吴锁平, 陈其龙, Wooden J L, Mazadab F K, Mattinson C. 2007. 柴达木盆地北缘大柴旦地区古生代花岗岩锆石SHRIMP 定年. 岩石学报, 23: 1861-1875

吴才来, 杨经绥, 许志琴, Wooden J L, Ireland T, 李海兵, 史仁灯, 孟 繁聪, 陈松永, Persng H, Mebom A. 2004. 柴达木盆地北缘古生代 超高压带中花岗质岩浆作用. 地质学报, 78: 658-674

杨永泰, 张宝民, 席萍, 余辉龙, 吴光大, 刘东. 2001. 柴达木盆地北 缘侏罗系展布规律新认识. 地层学杂志, 25: 154-159

雍拥, 肖文交, 袁超, 李继亮, 闩臻, 毛启贵. 2008. 中祁连东段花岗 岩LA-ICP-MS锆石U-Pb年龄及地质意义. 新疆地质, 26: 62-70

张海军, 王训练, 王勋, 周洪瑞. 2016. 柴达木盆地北缘全吉群红藻山 组凝灰岩锆石 $\mathrm{U}-\mathrm{Pb}$ 年龄及其地质意义. 地学前缘, 23: 202-218

张璐, 巴金, 陈能松, 王勤燕, 廖梵汐, 李晓彦. 2012. 全吉群碎屑锆 石的U-Pb年龄谱和微量元素: 基底热事件信息和早期演化启示. 地球科学——国地质大学学报, 37: 28-42

张璐, 廖梵汐, 巴金, 徐利盼, 王勤燕, 陈能松. 2011. 全吉地块花岗 片麻岩中镁铁质岩包体的矿物演化和锆石定年与古元古代区域 变质作用. 地学前缘, 18: 79-84

张涛, 张德会, 杨兵. 2014. 青海岗察岩体SHRIMP 锆石U-Pb年龄及 其地质意义. 岩石学报, 30: 2739-2748

周宾, 郑有业, 童海奎, 许荣科, 聂晓亮, 马超, 刘茜. 2014. 柴北缘早 古生代埃达克质花岗岩锆石定年及其地质意义. 现代地质, 28: 875-883

朱小辉, 陈丹玲, 刘良, 赵姣, 张乐. 2014. 柴北缘绿梁山地区早古生
代弧后盆地型蛇绿岩的年代学、地球化学及大地构造意义. 岩 石学报, 30: 822-834

Cao J, Wu M, Chen Y, Hu K, Bian L, Wang L, Zhang Y. 2012. Trace and rare earth element geochemistry of Jurassic mudstones in the northern Qaidam Basin, northwest China. Chem der Erde-Geo Chem, 72: $245-252$

Chen N, Gong S, Sun M, Li X, Xia X, Wang Q, Wu F, Xu P. 2009. Precambrian evolution of the Quanji Block, northeastern margin of Tibet: Insights from zircon $\mathrm{U}-\mathrm{Pb}$ and $\mathrm{Lu}-\mathrm{Hf}$ isotope compositions. J Asian Earth Sci, 35: 367-376

Chen N, Zhang L, Sun M, Wang Q, Kusky T M. 2012. U-Pb and Hf isotopic compositions of detrital zircons from the paragneisses of the Quanji Massif, NW China: Implications for its early tectonic evolutionary history. J Asian Earth Sci, 54-55: 110-130

Cheng F, Fu S, Jolivet M, Zhang C, Guo Z. 2016. Source to sink relation between the Eastern Kunlun Range and the Qaidam Basin, northern Tibetan Plateau, during the Cenozoic. Geol Soc Am Bull, 128: 258283

Cheng F, Jolivet M, Fu S, Zhang Q, Guan S, Yu X, Guo Z. 2014. Northward growth of the Qimen Tagh Range: A new model accounting for the Late Neogene strike-slip deformation of the SW Qaidam Basin. Tectonophysics, 632: 32-47

DeCelles P G, Gehrels G E, Quade J, Ojha T P, Kapp P A, Upreti B N. 1998. Neogene foreland basin deposits, erosional unroofing, and the kinematic history of the Himalayan fold-thrust belt, western Nepal. Geological Soc Am Bull, 110: 2-21

Dickinson W R, Suczek C A. 1979. Plate tectonics and sandstone compositions. Assoc Petrol Geol Bull, 63: 2164-2182

Duvall A R, Clark M K, Kirby E, Farley K A, Craddock W H, Li C, Yuan D Y. 2013. Low-temperature thermochronometry along the Kunlun and Haiyuan Faults, NE Tibetan Plateau: Evidence for kinematic change during late-stage orogenesis. Tectonics, 32: 1190-1211

Enkelmann E, Ratschbacher L, Jonckheere R, Nestler R, Fleischer M, Gloaguen R, Hacker B R, Zhang Y Q, Ma Y S. 2007. Cenozoic exhumation and deformation of northeastern Tibet and the Qinling: Is Tibetan lower crustal flow diverging around the Sichuan Basin? Geol Soc Am Bull, 118: 651-671

Gong S, Chen N, Wang Q, Kusky T M, Wang L, Zhang L, Ba J, Liao F. 2012. Early Paleoproterozoic magmatism in the Quanji Massif, northeastern margin of the Qinghai-Tibet Plateau and its tectonic significance: LA-ICPMS U-Pb zircon geochronology and geochemistry. Gondwana Res, 21: 152-166

Jian X, Guan P, Zhang D W, Zhang W, Feng F, Liu R J, Lin S D. 2013. Provenance of Tertiary sandstone in the northern Qaidam basin, northeastern Tibetan Plateau: Integration of framework petrography, heavy mineral analysis and mineral chemistry. Sediment Geol, 290: 
$109-125$

Jolivet M, Brunel M, Seward D, Xu Z, Yang J, Roger F, Tapponnier P, Malavieille J, Arnaud N, Wu C. 2001. Mesozoic and Cenozoic tectonics of the northern edge of the Tibetan plateau: Fission-track constraints. Tectonophysics, 343: 111-134

Liu S, Steel R, Zhang G. 2005. Mesozoic sedimentary basin development and tectonic implication, northern Yangtze Block, eastern China: record of continent-continent collision. J Asian Earth Sci, 25: 9-27

Liu S, Zhang G, Ritts B D, Zhang H, Gao M, Qian C. 2010. Tracing exhumation of the Dabie Shan ultrahigh-pressure metamorphic complex using the sedimentary record in the Hefei Basin, China. Geol Soc Am Bull, 122: 198-218

Ludwig K R. 2003. Mathematical-Statistical treatment of data and errors for ${ }^{230} \mathrm{Th} / \mathrm{U}$ geochronology. Rev Mineral Geochem. 52: 631-656

Mao L G, Xiao A C, Wu L, Li B L, Wang L Q, Lou Q Q, Dong Y P, Qin S H. 2014. Cenozoic tectonic and sedimentary evolution of southern Qaidam Basin, NE Tibetan Plateau and its implication for the rejuvenation of Eastern Kunlun Mountains. Sci China Earth Sci, 57: 2726-2739

Mattinson C G, Wooden J L, Liou J G, Bird D K, Wu C L. 2006. Geochronology and tectonic significance of Middle Proterozoic granitic orthogneiss, North Qaidam HP/UHP terrane, Western China. Mineral Petrol, 88: 227-241

Miller C F, Hatcher R D, Mark Harrison T, Coath C D, Gorisch E B. 1998. Cryptic crustal events elucidated through zone imaging and ion microprobe studies of zircon, southern Appalachian Blue Ridge, North Carolina-Georgia. Geology, 26: 419-422

Qian T, Liu S, Li W, Gao T, Chen X. 2015. Early-Middle Jurassic evolution of the northern Yangtze foreland basin: a record of uplift following Triassic continent-continent collision to form the Qinling-Dabieshan orogenic belt. Int Geol Rev, 57: 327-341

Ritts B D, Biffi U. 2001. Mesozoic northeast Qaidam basin: Response to contractional reactivation of the Qilian Shan, and implications for the extent of Mesozoic intracontinental deformation in central Asia. In: Hendrix M S, Davis G A, eds. Paleozoic and Mesozoic Tectonic Evolution of Central Asia: From Continental Assembly to Intracontinental Deformation: Boulder, Colorado. Geol Soc Am Bull, 194: 293-316

Shi R D, Yang J S, Wu C L, Iizuka T, Hirata T, Tsuyoshi I, Takafumi H. 2006. Island arc volcanic rocks in the north Qaidam UHP belt, northern Tibet plateau: Evidence for ocean-continent subduction preceding continent-continent subduction. J Asian Earth Sci, 28: 151-159

Sobel E R, Arnaud N, Jolivet M, Ritts B D, Brunei M. 2001. Jurassic to Cenozoic exhumation history of the Altyn Tagh Range, northwest China, constrained by ${ }^{40} \mathrm{Ar} /{ }^{39} \mathrm{Ar}$ and apatite fission track ther- mochronology. In: Hendrix M S, Davis G A, eds. Paleozoic and Mesozoic Tectonic Evolution of Central Asia: From Continental Assembly to Intracontinental Deformation. Geol Soc Am Bull, 194: 247 Song S, Niu Y, Su L, Wei C, Zhang L. 2014a. Adakitic (tonalitic-trondhjemitic) magmas resulting from eclogite decompression and dehydration melting during exhumation in response to continental collision. Geochim Cosmochim Acta, 130: 42-62

Song S, Niu Y, Su L, Xia X. 2013. Tectonics of the North Qilian orogen, NW China. Gondwana Res, 23: 1378-1401

Song S, Niu Y, Su L, Zhang C, Zhang L. 2014b. Continental orogenesis from ocean subduction, continent collision/subduction, to orogen collapse, and orogen recycling: The example of the North Qaidam UHPM belt, NW China. Earth-Sci Rev, 129: 59-84

Song S, Su L, Li X, Niu Y, Zhang L. 2012. Grenville-age orogenesis in the Qaidam-Qilian block: The link between South China and Tarim. Precambrian Res, 220-221: 9-22

Song S, Su L, Li X, Zhang G, Niu Y, Zhang L. 2010. Tracing the 850-Ma continental flood basalts from a piece of subducted continental crust in the North Qaidam UHPM belt, NW China. Precambrian Res, 183: 805-816

Song S, Su L, Niu Y, Zhang L, Zhang G. 2007. Petrological and geochemical constraints on the origin of garnet peridotite in the North Qaidam ultrahigh-pressure metamorphic belt, northwestern China. Lithos, 96: 243-265

Song S, Zhang L, Niu Y, Su L, Jian P, Liu D. 2005. Geochronology of diamond-bearing zircons from garnet peridotite in the North Qaidam UHPM belt, Northern Tibetan Plateau: A record of complex histories from oceanic lithosphere subduction to continental collision. Earth Planet Sci Lett, 234: 99-118

Song S, Zhang L, Niu Y, Su L, Song B, Liu D. 2006. Evolution from oceanic subduction to continental collision: A case study from the Northern Tibetan Plateau based on geochemical and geochronological data. J Petrol, 47: 435-455

Sun S, McDonough W F. 1989. Chemical and isotopic systematics of oceanic basalts: Implications for mantle composition and processes. Geol Soc London Spec Public, 42: 313-345

Tapponnier P, Peltzer G, Armijo R. 1986. On the mechanics of the collision between India and Asia. Geol Soc London Spec Publ, 19: 115-157

Tucker G E, Slingerland R. 1996. Predicting sediment flux from fold and thrust belts. Basin Res, 8: 329-349

Tung K, Yang H J, Yang H Y, Liu D Y, Zhang J X, Wan Y S, Tseng C Y. 2007. SHRIMP U-Pb geochronology of the zircons from the Precambrian basement of the Qilian Block and its geological significances. Chin Sci Bull, 52: 2687-2701

Vavra G, Gebauer D, Schmid R, Compston W. 1996. Multiple zircon 
growth and recrystallization during polyphase Late Carboniferous to Triassic metamorphism in granulites of the Ivrea Zone (Southern Alps): An ion microprobe (SHRIMP) study. Contrib Mineral Petrol, 122: $337-358$

Wang C, Li R, Li M, Meert J G, Peng Y. 2015. Palaeoproterozoic magmatic-metamorphic history of the Quanji Massif, Northwest China: Implications for a single North China-Quanji-Tarim craton within the Columbia supercontinent? Int Geol Rev, 57: 1772-1790

Wang E. 1997. Displacement and timing along the northern strand of the Altyn Tagh fault zone, Northern Tibet. Earth Planet Sci Lett, 150: $55-64$

Wang M, Song S, Niu Y L, Su L. 2014. Post-collisional magmatism: Consequences of UHPM terrane exhumation and orogen collapse, N. Qaidam UHPM belt, NW China. Lithos, 210-211: 181-198

Wang Q Y, Chen N S, Li X Y, Hao S, Chen H L. 2008. LA-ICPMS zircon

$\mathrm{U}-\mathrm{Pb}$ geochronological constraints on the tectonothermal evolution of the Early Paleoproterozoic Dakendaban Group in the Quanji Block, NW China. Chin Sci Bull, 53: 2849-2858

Wang Y, Zhang X, Wang E, Zhang J, Li Q, Sun G. 2005. 40Ar/39Ar thermochronological evidence for formation and Mesozoic evolution of the northern-central segment of the Altyn Tagh fault system in the northern Tibetan Plateau. Geol Soc Am Bull, 117: 1336-1346

Xiong Q, Zheng J, Griffin W L, O'Reilly S Y, Pearson N J. 2012. Decoupling of $\mathrm{U}-\mathrm{Pb}$ and $\mathrm{Lu}-\mathrm{Hf}$ isotopes and trace elements in zircon from the UHP North Qaidam orogen, NE Tibet (China): Tracing the deep subduction of continental blocks. Lithos, 155: 125-145

Xu X, Song S, Su L, Li Z, Niu Y, Allen M B. 2015. The 600-580Ma continental rift basalts in North Qilian Shan, northwest China: Links between the Qilian-Qaidam block and SE Australia, and the reconstruction of East Gondwana. Precambrian Res, 257: 47-64

Xu X, Song S, Allen M B, Ernst R E, Niu Y, Su L. 2016. An 850-820Ma LIP dismembered during breakup of the Rodinia supercontinent and destroyed by Early Paleozoic continental subduction in the northern Tibetan Plateau, NW China. Precambrian Res, 282: 52-73

Yin A, Dang Y, Zhang M, McRivette M W, Burgess W P, Chen X. 2007.
Cenozoic tectonic evolution of Qaidam Basin and its surrounding regions (Part 2): Wedge tectonics in southern Qaidam Basin and the Eastern Kunlun Range. In: Sears J W, Harms T A, Evenchick C A, eds. Whence the Mountain? Inquiries into the Evolution of Orogenic Systems: A Volume in Honor of Raymond A. Price. Geol Soc Am Bull Spec Paper, 433: 369-390

Yu S, Zhang J, Li H, Hou K, Mattinson C G, Gong J. 2013. Geochemistry, zircon $\mathrm{U}-\mathrm{Pb}$ geochronology and $\mathrm{Lu}-\mathrm{Hf}$ isotopic composition of eclogites and their host gneisses in the Dulan area, North Qaidam UHP terrane: New evidence for deep continental subduction. Gondwana Res, 23: 901-919

Yuan W M, Zhang X T, Dong J Q, Tang Y H, Yu F S, Wang S C. 2003. A new vision of the intracontinental evolution of the eastern Kunlun Mountains, Northern Qinghai-Tibet plateau, China. Radiat Measurements, 36: 357-362

Zhang C, Zhang L, Roermund H V, Song S, Zhang G. 2011. Petrology and SHRIMP U-Pb dating of Xitieshan eclogite, North Qaidam UHP metamorphic belt, NW China. J Asian Earth Sci, 42: 752-767

Zhang G, Song S, Zhang L, Niu Y. 2008. The subducted oceanic crust within continental-type UHP metamorphic belt in the North Qaidam, NW China: Evidence from petrology, geochemistry and geochronology. Lithos, 104: 99-118

Zhang J X, Mattinson C G, Yu S Y, Li J P, Meng F C. 2010. U-Pb zircon geochronology of coesite-bearing eclogites from the southern Dulan area of the North Qaidam UHP terrane, northwestern China: Spatially and temporally extensive UHP metamorphism during continental subduction. J Metamorph Geol, 28: 955-978

Zhang L, Wang Q, Chen N, Sun M, Santosh M, Ba J. 2014. Geochemistry and detrital zircon $\mathrm{U}-\mathrm{Pb}$ and $\mathrm{Hf}$ isotopes of the paragneiss suite from the Quanji massif, SE Tarim Craton: Implications for Paleoproterozoic tectonics in NW China. J Asian Earth Sci, 95: 33-50

Zhang P Z, Shen Z, Wang M, Gan W, Bürgmann R, Molnar P, Wang Q, Niu Z, Sun J, Wu J, Hanrong S, Xinzhao Y. 2004. Continuous deformation of the Tibetan Plateau from global positioning system data. Geology, 32: 809-812 